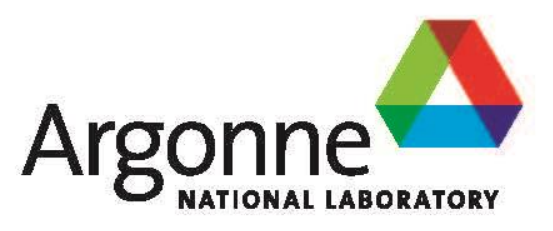

ANL/NE-16/2

\title{
Towards a Method of Rapid Extraction of Strontium-90 from Urine: Urine Pretreatment and Alkali Metal Removal
}

Nuclear Engineering Division 


\section{Acknowledgment}

Work supported by the Center for Disease Control and Prevention under agreement number 08FED894832.

About Argonne National Laboratory

Argonne is a U.S. Department of Energy laboratory managed by UChicago Argonne, LLC under contract DE-AC02-06 CH11357. The Laboratory's main facility is outside Chicago, at 9700 South Cass Avenue, Argonne, Illinois 60439. For information about Argonne and its pioneering science and technology programs, see www.anl.gov.

\section{DOCUMENT AVAILABILITY}

Online Access: U.S. Department of Energy (DOE) reports produced after 1991 and a growing number of pre-1991 documents are available free via DOE's SciTech Connect (http://www.osti.gov/scitech/)

Reports not in digital format may be purchased by the public from the National Technical Information Service (NTS):

U.S. Department of Commerce

National Technical Information Service

5301 Shawnee Rd

Alexandria, VA 22312

www.ntis.gov

Phone: (800) 553-NTIS (6847) or (703) 605-6000

Fax: (703) 605-6900

Email: orders@ntis.gov

Reports not in digital format are available to DOE and DOE contractors from the Office of Scientific and Technical Information (OST):

U.S. Department of Energy

Office of Scientific and Technical Information

P.O. Box 62

Oak Ridge, TN 37831-0062

wum.osti.gov

Phone: (865) 576-8401

Fax: (865) 576-5728

Email: reports@osti.gov

\section{Disclaimer}

This report was prepared as an account of work sponsored by an agency of the United States Government. Neither the United States Government nor any agency thereof, nor UChicago Argonne, LLC, nor any of their employees or officers, makes any warranty, express or implied, or assumes any legal liability or responsibility for the accuracy, completeness, or usefulness of any information, apparatus, product, or process disclosed, or represents that its use would not infringe privately owned rights. Reference herein to any specific commercial product, process, or service by trade name, trademark, manufacturer, or otherwise, does not necessarily constitute or imply its endorsement, recommendation, or favoring by the United States Government or any agency thereof. The views and opinions of document authors expressed herein do not necessarily state or reflect those of the United States Government or any agency thereof, Argonne National Laboratory, or UChicago Argonne, LLC. 


\section{Towards a Method of Rapid Extraction of Strontium-90 from Urine: Urine Pretreatment and Alkali Metal Removal}

by

C. Hawkins, M. Dietz, M. Kaminski, C. Mertz, and I. Shkrob

Nuclear Engineering Division, Argonne National Laboratory

March 2016 



\begin{abstract}
A technical program to support the Centers of Disease Control and Prevention is being developed to provide an analytical method for rapid extraction of Sr-90 from urine, with the intent of assessing the general population's exposure during an emergency response to a radiological terrorist event. Results are presented on the progress in urine sample preparation and chemical separation steps that provide an accurate and quantitative detection of $\mathrm{Sr}-90$ based upon an automated column separation sequence and a liquid scintillation assay. Batch extractions were used to evaluate the urine pretreatment and the column separation efficiency and loading capacity based upon commercial, extractant-loaded resins. An efficient pretreatment process for decolorizing and removing organics from urine without measurable loss of radiostrontium from the sample was demonstrated. In addition, the Diphonix ${ }^{\circledR}$ resin shows promise for the removal of high concentrations of common strontium interferents in urine as a first separation step for Sr-90 analysis.
\end{abstract}




\section{Table of Contents}

ABSTRACT i

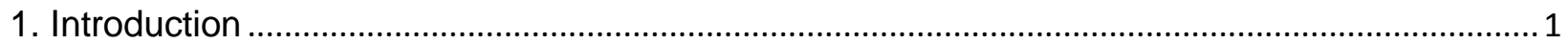

2. Urine Pretreatment ........................................................................... Error! Bookmark not defined.

3. Metals Separations ................................................................................ Error! Bookmark not defined.

3.1 $\mathrm{D}_{\mathrm{Sr}}$ versus $[\mathrm{MSA}]$ on Sr Resin .................................................. Error! Bookmark not defined.

3.2 Why Diphonix® Resin for Initial Strontium Sorption? ................. Error! Bookmark not defined.

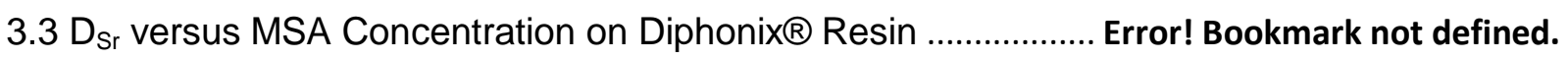

3.4 Strontium Uptake Suppression by Potassium and Calcium on Diphonix® .. Error! Bookmark not defined.

3.5 $\mathrm{D}_{\mathrm{Na}}$ versus MSA Concentration on Diphonix® Resin.......

Error! Bookmark not defined.

3.6 $\mathrm{D}_{\mathrm{Sr}}$ and $\mathrm{D}_{\mathrm{Na}}$ versus MSA Concentrations with $\mathrm{NaCl} / \mathrm{KCl}$ on Diphonix® Resin Error! Bookmark not defined.

3.7 $\mathrm{D}_{\mathrm{Sr}}$ versus MSA Concentration in Urine on Diphonix® Resin - Urine Treated with MSA and Charcoal. Error! Bookmark not defined.

4. Conclusions Error! Bookmark not defined.

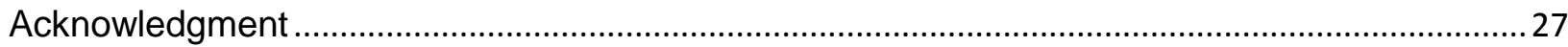

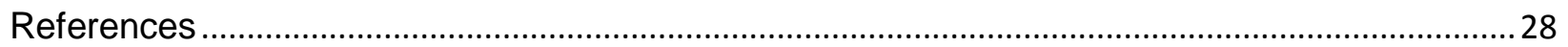




\section{List of Figures}

Figure 1: General Sample Preparation Procedure for Extraction and Recovery 5

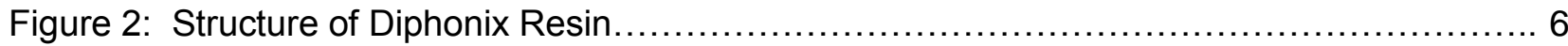

Figure 3: $\mathrm{D}_{\mathrm{Sr}}$ vs. $\mathrm{H}_{3} \mathrm{O}^{+}$Concentration on Diphonix ${ }^{\circledR}$ Resin (Wet Weight Basis) .................... 10

Figure 4: $\mathrm{D}_{\mathrm{Sr}}$ vs. $\mathrm{H}_{3} \mathrm{O}^{+}$Concentration on Diphonix $\circledast$ Resin (Dry Weight Basis)..................... 11

Figure 5: $\mathrm{D}_{\mathrm{Sr}}$ vs. $\mathrm{Ca}^{2+}$ and $\mathrm{K}^{+}$Concentration in $0.40 \mathrm{M} \mathrm{MSA}$ on Diphonix $\circledast$ Resin for a Phase Ratio of 1:20 (g/mL, Wet Weight Basis) Measured by Radiotracer.................................. 13

Figure 6: $D_{\mathrm{Na}}$ and $\mathrm{D}_{\mathrm{Sr}}$ vs. $\mathrm{H}_{3} \mathrm{O}^{+}$Concentration on Diphonix $(\mathrm{R}$ Resin................................. 15

Figure 7: $D_{\mathrm{Na}}$ and $\mathrm{D}_{\mathrm{Sr}}$ vs. MSA Concentration with $100 \mathrm{mM} \mathrm{NaCl} / \mathrm{KCl}$ on Diphonix® Resin for a Phase Ratio of 1:20 (g/mL, Wet Weight Basis) Measured by Radiotracer.

Figure 8: $D_{\mathrm{Na}}$ and $D_{\mathrm{Sr}}$ vs. MSA Concentration with $100 \mathrm{mM} \mathrm{NaCl} / \mathrm{KCl}$ on Diphonix® Resin for a Phase Ratio of 1:20 (g/mL, Wet Weight Basis) Measured by Radiotracer and ICP-AES

(Na only)

Figure 9. $\mathrm{D}_{\mathrm{Sr}}$ vs. $\mathrm{NaCl} / \mathrm{KCl}$ Concentration in $0.1 \mathrm{M}$ and $0.2 \mathrm{M} \mathrm{MSA}$ on Diphonix ${ }^{\circledR}$ Resin (Dry Weight Basis) for 1:10, 1:20, and 1:30 Phase Ratios $(\mathrm{g} / \mathrm{mL})$. .

Figure 10: $\mathrm{D}_{\mathrm{Sr}}$ vs. Ionic Strength (I) in $0.1 \mathrm{M}$ and $0.2 \mathrm{M} \mathrm{MSA}$ on Diphonix ${ }^{\circledR}$ Resin (Dry Weight Basis) for 1:10, 1:20, and 1:30 Phase Ratios $(\mathrm{g} / \mathrm{mL})$.

Figure 11: $D_{\mathrm{Na}}$ vs. $\mathrm{NaCl} / \mathrm{KCl}$ Concentration in $0.1 \mathrm{M}$ and $0.2 \mathrm{M}$ MSA on Diphonix® Resin (Dry Weight Basis) for 1:10, 1:20, and 1:30 Phase Ratios $(\mathrm{g} / \mathrm{mL}) \ldots$

Figure 12: $D_{\mathrm{Na}}$ vs. Ionic Strength (I) in $0.1 \mathrm{M}$ and 0.2 M MSA on Diphonix® Resin (Dry Weight Basis) for 1:10, 1:20, and 1:30 Phase Ratios $(\mathrm{g} / \mathrm{mL})$.

Figure 13: $D_{\mathrm{Sr}}$ vs. MSA Concentration in Human Urine on Diphonix $\circledast$ Resin for 1:10, 1:20, and 1:30 Phase Ratios $(\mathrm{g} / \mathrm{mL}$, wet). 


\section{List of Tables}

Table 1: Sr-85 Recovery from Urine Decolorizing Agents - Charcoal and Amberlite XAD-7........ 3

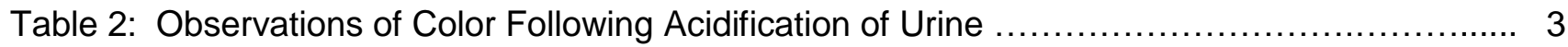

Table 3: Observations of Color Following Decolorization Treatment of Acidified Urine with

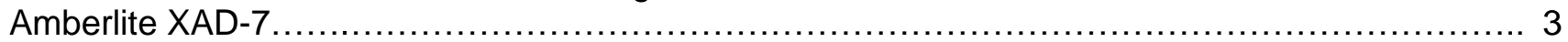

Table 4: $D_{S r}$ vs. MSA Concentration on Sr Resin in Presence and Absence of Nitric Acid ........ 6

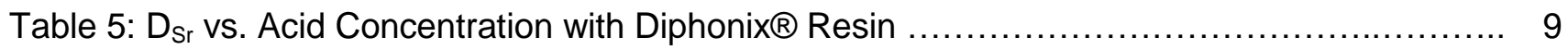

Table 6: Sr-85 Uptake Suppression on Diphonix® Resin by Calcium and Potassium in $0.4 \mathrm{M} \mathrm{MSA}$

Table 7: Spot Checks for Sr Uptake on Diphonix® Resin Suppression by $\mathrm{Ca}^{2+}$ and $\mathrm{K}^{+}$in $0.1 \mathrm{M} \mathrm{MSA}$

Table 8: $D_{\mathrm{Na}}$ and $\mathrm{D}_{\mathrm{Sr}}$ vs. Acid Concentration on Diphonix® Resin

Table 9: Acid Dependency Data for Sr and Na Extraction by Diphonix® Resin from 0-0.2 M

$\mathrm{NaCl} / \mathrm{KCl}$ in $0.1 \mathrm{M}$ and $0.2 \mathrm{M} \mathrm{MSA}$ for $1: 10,1: 20$, and 1:30 Phase Ratios $(\mathrm{g} / \mathrm{mL})$....

Table 10: Strontium Recoveries from Acidified Urine Charcoal

Treatment.

Table 11: Average Acid Dependencies for Strontium Extraction from Acidified, Charcoal-Treated Human Urine 


\section{Introduction}

An analytical method for the rapid extraction of Sr-90 from urine is being developed for the evaluation of individuals contaminated with radionuclides from a radiological terrorist event. This method will allow rapid evaluation and screening of individuals for possible exposure to $\mathrm{Sr}-90$ by a critical medical management team and will allow contaminated individuals to be administered chemical countermeasures in the critical time frame after initial exposure. The method being developed will minimize the amount of urine for Sr-90 detection and will allow quantification at levels corresponding to U.S. NRC recommended annual limits of intake (ALI) for exposure to Sr-90 [1].

Current methods used for determination of Sr-90 in urine involve various concentration and separations steps [2-5], which are tedious and time-consuming and require a skilled technician. These steps have been employed to obtain quantitative recovery of strontium from urine and to minimize the detrimental effects of numerous interferences in the separation of strontium from urine. In an effort to speed up strontium separation and detection, we have examined various separation schemes to develop a simple and robust process. Normal human urine consists of ions (sodium, potassium, calcium, etc.) and organic molecules (urea, creatinine, uric acid, and smaller amounts of carbohydrates, enzymes, fatty acids, hormones, pigments, mucins, etc.). The composition of urine can vary greatly between subjects and is highly dependent upon diet. A certified human urine reference material is reported to have elemental concentrations of some ions that interfere with strontium separation: $0.14 \mathrm{M} \mathrm{Na}^{+}, 0.034$ $\mathrm{M} \mathrm{K}^{+}$, and $0.0048 \mathrm{M} \mathrm{Ca}^{2+}[6]$. These concentrations are high compared to the trace quantities of strontium required for the proposed separations.

The initial step in our process employs acidification of the urine with the intent of destroying any existing strontium complexes in urine and maximizing complexation onto extractant-loaded particles. Next, the method will exploit Sr-90 pre-concentration and separation technologies to allow analysis and detection from urine matrix interferents. The goal of these separations would allow triage decisions to be made based upon low limits of quantitation for potentially exposed patients. Detection of Sr-90 concentrations at greater than 10 times the ALI for exposure to Sr-90 would trigger patient treatment. However, detection of Sr-90 quantities below $1 \mathrm{ALI}$ with confidence would be necessary for release of patients without treatment. 


\section{Urine Pretreatment}

Human urine contains organic substances (i.e., creatinine, urea, and bilirubin) whose presence can lead to fouling of extraction chromatographic media, excessive back pressure, and poor separation. Bilirubin is a metabolite of heme, is excreted in bile and urine, and is responsible for much of the yellow color observed in mammalian urine. Colored compounds such as bilirubin can be strong fluorescence/color quenchers in liquid scintillation analysis (LSA) of urine samples, diminishing counting efficiency. Removal or reduction of these interferences will improve the minimum detectable activity of the LSA method.

Achieving high recovery of radiostrontium requires minimal losses of analyte from the steps that precede the extraction. Work by Sadi et al. [7] has demonstrated that acidification is necessary for the decolorization of urine. These authors also found significant losses of $\mathrm{Sr}-90$ on charcoal (50\%) from 1\% hydrochloric acid, in contrast to quantitative recovery of Sr-90 on Eichrom's pre-filter material. Our initial flow diagram for the urine pretreatment was ambiguous as to the order of use of Sr resin and Diphonix ion exchange resin in the sample stream. In either case, use of nitric acid or methane sulfonic acid (MSA) provides the flexibility for introduction of the sample stream to a variety of extraction chromatographic media, and subsequent LSA.

To evaluate the reduction of interfering organic substances in human urine and the extent of strontium lost in this process, Sr-85 spiked urine was treated with either concentrated nitric acid or neat MSA, and was contacted with activated charcoal or Amberlite XAD-7 prefilter beads (100-120 mesh). All samples were treated in a weightto-volume ratio of 1:100. A single lot of normal human urine with a dark yellow color was used. Color and consistency were evaluated as a qualitative measure of organics removal. Strontium-85 was employed instead of Sr-90 to facilitate analyses during these development studies. Gamma count rates were used for controls and samples to calculate the recovery of Sr-85 for each acid concentration shown in Table 1. The observed colors upon acidification and after sustained contact with XAD-7 are listed in Tables 2 and 3 , respectively. All samples treated with charcoal were immediately decolorized upon first contact and settling of the charcoal. The XAD-7 beads were much slower in uptake of color, reaching apparent equilibrium after repeated 1-2 min of vigorous mixing and standing for $30 \mathrm{~min}$ twice. All treated samples were clear aqueous solutions with no emulsion or bubble formation. 
Table 1: Sr-85 Recovery from Urine Decolorizing Agents - Charcoal and Amberlite XAD-7

\begin{tabular}{|c|c|c|c|c|}
\hline [Acid] & \begin{tabular}{|c|} 
HNO3/Charcoal \\
$\%$ Recovery
\end{tabular} & Relative Uncertainty & $\begin{array}{c}\text { MSA/Charcoal } \\
\% \text { Recovery }\end{array}$ & $\begin{array}{c}\text { Relative } \\
\text { Uncertainty }\end{array}$ \\
\hline $0.001 \mathrm{M}$ & $87.2 \%$ & $2.3 \%$ & $91.2 \%$ & $2.0 \%$ \\
\hline $0.01 \mathrm{M}$ & $96.0 \%$ & $2.2 \%$ & $93.3 \%$ & $1.0 \%$ \\
\hline $0.1 \mathrm{M}$ & $98.4 \%$ & $2.1 \%$ & $96.3 \%$ & $1.9 \%$ \\
\hline $1 \mathrm{M}$ & $97.0 \%$ & $2.3 \%$ & $99.4 \%$ & $1.6 \%$ \\
\hline $4 M$ & $98.0 \%$ & $2.6 \%$ & $98.8 \%$ & $2.2 \%$ \\
\hline $8 \mathrm{M}$ & $98.2 \%$ & $1.8 \%$ & & \\
\hline
\end{tabular}

\begin{tabular}{|c|c|c|c|c|}
\hline [Acid] & $\begin{array}{c}\text { HNO3/XAD-7 \% } \\
\text { Recovery }\end{array}$ & Relative Uncertainty & $\begin{array}{c}\text { MSA/XAD-7 \% } \\
\text { Recovery }\end{array}$ & $\begin{array}{c}\text { Relative } \\
\text { Uncertainty }\end{array}$ \\
\hline $0.001 \mathrm{M}$ & $99.1 \%$ & $1.2 \%$ & $114 \%$ & $1.6 \%$ \\
\hline $0.01 \mathrm{M}$ & $98.3 \%$ & $2.3 \%$ & $100 \%$ & $2.4 \%$ \\
\hline $0.1 \mathrm{M}$ & $97.3 \%$ & $5.6 \%$ & $97.2 \%$ & $1.5 \%$ \\
\hline $1 M$ & $98.5 \%$ & $1.6 \%$ & $98.8 \%$ & $3.2 \%$ \\
\hline $4 M$ & $99.3 \%$ & $1.1 \%$ & $99.3 \%$ & $2.0 \%$ \\
\hline $8 M$ & $99.3 \%$ & $1.6 \%$ & & \\
\hline
\end{tabular}

Table 2: Observations of Color Following Acidification of Urine

\begin{tabular}{|r|c|r|c|}
\hline [HNO3], M & Color of Liquid & [MSA], M & Color of Liquid \\
\hline \hline 0.001 & Light Yellow & 0.001 & Light Yellow \\
\hline 0.01 & Light Yellow & 0.01 & Light Yellow \\
\hline 0.10 & Light Orange & 0.10 & Yellow-orange \\
\hline 1.0 & Light Orange & 1.0 & Orange \\
\hline 4.0 & Bright Yellow & 4.0 & Red-brown \\
\hline 8.0 & Pale Yellow & & \multicolumn{1}{|c|}{} \\
\hline
\end{tabular}

Table 3: Observations of Color Following Decolorization Treatment of Acidified Urine with Amberlite XAD-7

\begin{tabular}{|r|c|c|r|c|c|}
\hline [HNO3], M & Color of Liquid & Color of XAD-7 Beads & [MSA], M & Color of Liquid & Color of XAD-7 Beads \\
\hline \hline 0.001 & Nearly Colorless & Light Orange & 0.001 & Nearly Colorless & Light Orange \\
\hline 0.01 & Nearly Colorless & Light Orange & 0.01 & Nearly Colorless & Light Orange \\
\hline 0.10 & Nearly Colorless & Orange & 0.10 & Colorless & Orange \\
\hline 1.0 & Nearly Colorless & Red-brown & 1.0 & Colorless & Red-brown \\
\hline 4.0 & Light Yellow & Orange & 4.0 & Light Orange & Purple-brown \\
\hline 8.0 & Pale Yellow & Pale Yellow & & & \\
\hline
\end{tabular}


Table 1 shows nearly quantitative recovery of strontium for charcoal at acid concentrations of $0.10 \mathrm{M}$ and greater. All acid concentrations for XAD-7 treatment led to quantitative recovery of strontium. It is not certain why the recovery for XAD-7 and $0.001 \mathrm{M} \mathrm{MSA}$ is so high (114\%). Prior work by Shkrob [personal communication, October 2009] suggests that MSA is more efficient at removing organic substances when combined with charcoal. Taking Sr-85 recovery with complete and rapid decolorization into account, we inferred that the suggested conditions for the pretreatment of urine are acidification to 0.1-1.0 M MSA, contact with activated charcoal, and filtering before sending the stream to an extraction stage.

\section{Metals Separations}

In these studies, various extractant systems employing Diphonix® resin and $\mathrm{Sr}$ resin were evaluated for the rapid and efficient extraction of strontium from treated urine and urine simulants in the presence of alkali and alkaline earth elements.

For simplicity and ease of detection, all of the following experiments were performed with $\mathrm{Sr}-85$, a radionuclide whose chief mode of decay is by electron capture to an $\mathrm{Rb}-85$ isomer. The subsequent emission of a gamma ray $(0.514 \mathrm{MeV})$ to groundstate Rb-85 is the detected event. All metal distribution coefficients $\left(D_{M}\right)$ are calculated as weight distribution coefficients by

$$
D_{M}=\frac{\left(C_{0}-C_{f}\right)}{C_{f}} * \frac{V}{m},
$$

where $\mathrm{C}_{0}$ and $\mathrm{C}_{f}$ are the counts per minute for the control (pre-extraction) and sample (post extraction), respectively; $\mathrm{V}$ is the volume (in $\mathrm{mL}$ ) of the liquid phase; and $\mathrm{m}$ is the mass (in grams) of resin or solid extraction phase.

All $D_{M}$ dependency data are plotted in the accompanying figures with axes in logarithmic base 10 scale.

\section{1 $\mathrm{D}_{\mathrm{Sr}}$ versus [MSA] on Sr Resin}

Since MSA is the leading reagent for urine pre-treatment, it was necessary to evaluate the effect of MSA on strontium extraction by Sr resin. If MSA could be used as a substitute for nitric acid on $\mathrm{Sr}$ resin, or if it did not interfere with extraction, then its use in pre-treatment would not require an extra step for its removal prior to a step using $\mathrm{Sr}$ resin. Demonstrating the effect of MSA on strontium extraction by Sr resin was achieved by contacting Sr-85 spiked aqueous MSA at various concentrations (0-4 M) with bulk Sr resin in the presence and absence of $3 \mathrm{M}$ nitric acid. All samples were vortex mixed for 
2 min, allowed to stand approximately $10 \mathrm{~min}$, then vortex mixed for $10 \mathrm{sec}$ frequently for the next $10 \mathrm{~min}$ and allowed to settle. To ensure that resin capacity was not exceeded and that subtle changes in strontium uptake could be observed, we used 1:50 and $1: 20(\mathrm{~g} / \mathrm{mL})$ ratios of wet resin to aqueous phase for samples with and without nitric acid, respectively. Due to a convergence in the densities of the resin and 3-4 M MSA solutions, we had to filter the suspended beads at these conditions. A general experimental scheme for the extraction and recovery determinations is given in Figure 1.

Spike Stocks with radiotracer and take $100 \mu \mathrm{L}$ aliquots for control analysis by gamma counting<smiles>C=[12CH]</smiles>

Transfer appropriate volume of spiked stocks to vials with extractant

\author{
$\downarrow$ \\ Vortex mix for $2 \mathrm{~min}$, let stand $10 \mathrm{~min}$ \\ Vortex mix for $10 \mathrm{~s}$ frequentlyfor subsequent $10 \mathrm{~min}$ \\ $\downarrow$ \\ Ensure that solid phase is not suspended by settling, \\ centrifugation, or filtering \\ $\downarrow$ \\ Take at least duplicate aliquots of $100 \mu \mathrm{L}$ from each \\ sample for analysis by gamma counting
}

Figure 1: General Sample Preparation Procedure for Extraction and Recovery Determination 
The summary of these results presented in Table 4 indicates that MSA has no effect on the uptake of strontium by $\mathrm{Sr}$ resin from 0 to $4 \mathrm{M}$ in aqueous solution. In the presence of $3 \mathrm{M}$ nitric acid, the $\mathrm{D}_{\mathrm{Sr}}$ showed no dependency on MSA concentration. Even the minor reduction in $D_{S r}$ from 0 to $4 \mathrm{M} \mathrm{MSA}$ is within the actual experimental error estimated for these types of experiments $( \pm 10 \%)$. Moreover, in the absence of nitric acid, no significant extraction of strontium was possible.

Table 4: $D_{\text {Sr }}$ vs. MSA Concentration on Sr Resin in Presence and Absence of Nitric Acid

\begin{tabular}{|c|c|c|c|c|c|}
\hline Condition & $\mathrm{D}_{\mathrm{Sr}}$ & $\begin{array}{c}\text { Relative } \\
\text { Uncertainty }\end{array}$ & Condition & $\mathbf{D}_{\mathrm{Sr}}$ & $\begin{array}{c}\text { Relative } \\
\text { Uncertainty }\end{array}$ \\
\hline $3 \mathrm{MHNO} 3$ & 150 & $0.9 \%$ & 0 M MSA & 1.95 & $1.5 \%$ \\
\hline 0.25 M MSA3M HNO3 & 150 & $0.7 \%$ & $0.25 \mathrm{MMSA}$ & 0.37 & $1.8 \%$ \\
\hline 0.50 M MSA3M HNO3 & 157 & $1.9 \%$ & $0.50 \mathrm{M} M S A$ & 0.23 & $0.7 \%$ \\
\hline $1.00 \mathrm{M}$ MSA3M HNO3 & 157 & $0.7 \%$ & 1.00 M MSA & 0.20 & $1.0 \%$ \\
\hline 1.50 M MSA3M HNO3 & 160 & $2.3 \%$ & $1.50 \mathrm{MMSA}$ & 0.33 & $0.2 \%$ \\
\hline 2.00 M MSA3M HNO3 & 167 & $6.4 \%$ & $2.00 \mathrm{M} \mathrm{MSA}$ & 0.75 & $1.8 \%$ \\
\hline 3.00 M MSA3M HNO3 & 164 & $5.7 \%$ & 3.00 $\mathrm{M} \mathrm{MSA}^{*}$ & 1.79 & $0.8 \%$ \\
\hline 4.00 M MSA3M HNO3 & 138 & $1.6 \%$ & 4.00 $\mathrm{M} \mathrm{MSA}^{*}$ & 1.68 & $2.7 \%$ \\
\hline
\end{tabular}

* Samples filtered by Wheaton 25-PP disk filters to remove suspended resin beads

\subsection{Why Diphonix ${ }^{\circledR}$ Resin for Initial Strontium Sorption?}

Diphonix ${ }^{\circledR}$ resin is a geminally-substituted diphosphonic acid gel-type resin with a strong affinity for trivalent and tetravalent metals. Constructed of a polystyrene/divinylbenzene matrix in a spherical bead form, this resin is polyfunctional, containing gem-diphosphonic and sulfonic acid groups bonded to the polymer matrix [8]. Figure 2 is a structural representation of the repeating functional groups in the polymer.

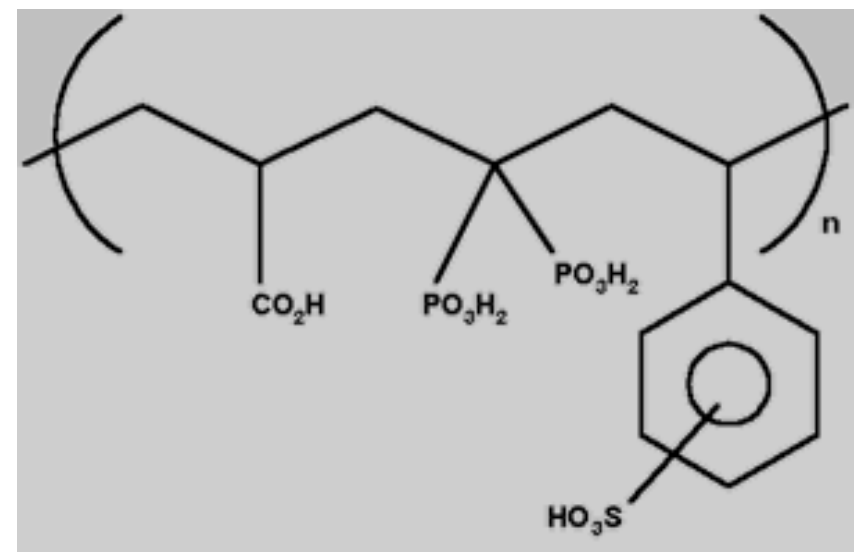

Figure 2: Structure of Diphonix Resin 
Though Sr resin is demonstrably selective for strontium over most metals, it has neither the selectivity nor capacity to resolve strontium from the other metals present in urine at millimolar quantities. Previous methods have used a traditional pre-treatment of precipitation and ashing, followed by at least three columns with differing selectivities, in order to analyze multiple components in urine [9]. Running the pre-treated sample through Diphonix ${ }^{\otimes}$ resin before the $\mathrm{Sr}$ resin offers several advantages: selectivity, capacity, and compatibility with a low acid pre-treatment. As the first extraction chromatographic platform in the sample stream, Diphonix ${ }^{\circledR}$ resin can load all metals (to a reasonable concentration at a given resin-to-aqueous phase ratio) in a low acid matrix and elute strontium with a modest increase in acid. Adding concentrated nitric acid to the strontium elution volume to attain $3 \mathrm{M} \mathrm{HNO}_{3}$ will then provide the conditions to load a Sr resin column. The Sr resin may be reserved for when other divalent metals need to be separated from strontium, especially calcium, for which it is well suited, having an $\mathrm{Sr} / \mathrm{Ca}$ selectivity of 400 at $3 \mathrm{M}$ nitric acid.

Iron, aluminum, actinides, and lanthanides are very strongly retained on the Diphonix ${ }^{\circledR}$ resin up to acidities as high as $4 \mathrm{M} \mathrm{HNO}_{3}\left(\mathrm{D} \sim 10^{2}\right.$ to $10^{3}$ for trivalents and $\mathrm{D}$ $\sim 10^{4}$ for tetravalents) [10]. This relatively flat dependency is largely due to the formation of strong complexes with the phosphoryl groups by these metal species, without exchange of protons [10]. Consequently, the ubiquitous occurrence of $Y-90$ in secular equilibrium with Sr-90 is not likely to cause LSA interference, because Y(III) will be retained by the column under conditions that elute strontium. Acid dependencies for alkaline earth metals and alkali metals indicate metal uptake with the displacement of protons as an inverse function of acid concentration to the power of the charge on the ion. Thus, it is expected that $\mathrm{D}_{\mathrm{Sr}} \mathrm{vs}$. $\left[\mathrm{H}_{3} \mathrm{O}^{+}\right]$will have a slope of approximately minus two. Therefore, $D_{M}$ for a given alkaline earth metal will often be an order of magnitude or greater than that of alkali metals under the same conditions.

Work by Dietz et al. summarizes the acid dependencies of alkaline earth metal uptake on Diphonix ${ }^{\circledR}$ resin and other ion-exchange resins [11]. Although alkaline earth retention is better on Bio-Rad AG $50 \mathrm{~W}-\mathrm{X} 8$ and AG MP-50 by orders of magnitude, these resins have cross-linked sulfonic acid functionalities only and are, therefore, not likely to behave like Diphonix ${ }^{\circledast}$ resin for trivalent and tetravalent metals. Our interest here is to analyze selectively and rapidly for radiostrontium only, and thus we have the luxury of batch separation and disposal of these other metals-alkali metals by washing, and trivalent and tetravalent metals by retention on the resin. It is important to note that for the Bio-Rad resins, strontium retention is quite strong over a wide range of acidities, complicating its subsequent recovery from the column.

Reasons for using Diphonix ${ }^{\circledR}$ resin in the initial cleanup of the urine matrix include the possibility of overloading a single extraction chromatographic column, the 
requirement for a prohibitively large bed volume to achieve the desired separations on a column of $\mathrm{Sr}$ resin alone, and the need for extra steps to minimize interference from potassium and/or sodium. Millimolar quantities of sodium, potassium, and calcium found in human urine pose the greatest hurdle for retaining nanomolar to picomolar quantities of radiostrontium. Our efforts have, therefore, focused on gaining an understanding of the general retention characteristics of strontium on Diphonix resin and the competition between strontium, sodium, potassium, and calcium in a range of low MSA concentrations ( 0 to $0.4 \mathrm{M}$ ).

\section{3 $\mathrm{D}_{\mathrm{Sr}}$ versus MSA Concentration on Diphonix® Resin}

The first step in characterizing Diphonix ${ }^{\circledR}$ resin with MSA, when all reported studies have involved nitric acid or hydrochloric acid, was to determine the MSA dependencies with and without nitric acid. Our approach was the same as the above $\mathrm{Sr}$ resin study, with the following differences: presence and absence of $0.5 \mathrm{M}$ nitric acid and contact with Diphonix ${ }^{\circledR}$ resin (50-100 mesh) at 1:33 to 1:50 resin:aqueous ratios $(\mathrm{g} / \mathrm{mL})$. Strontium distribution data for different MSA acid concentrations in the presence and absence of $0.5 \mathrm{M}$ nitric acid are given in Table 5 . Figure 3 plots $D_{S r}$ versus the overall acid concentration for the MSA alone and MSA plus $0.5 \mathrm{M} \mathrm{HNO}_{3}$ conditions. The curves reveal that for these two comparably strong acids $\left(\mathrm{pK}_{\mathrm{a}}=-1.5\right.$ for $\mathrm{HNO}_{3}$ and -2 for MSA), the retention of strontium is dominated by the cation-exchange mode, as described in the introduction to this section. No significant difference is observed in the curves for either set of conditions up to approximately $2 \mathrm{M}$ acid. Assuming a $36 \%$ dry weight basis for the resin (based on triplicate results for $0.3 \mathrm{~g}$ of 100-200 mesh resin, data not presented), the curves in Figure 4 compare well with published nitric acid dependencies [12]. The chief differences between the published values and the "dry" $D_{S r}$ here may be due to the water content between the lot used for this study and that analyzed for water content. Therefore, it can be concluded that the use of MSA on Diphonix resin will result in the same retention of strontium as when using nitric acid. 
Table 5: $\mathrm{D}_{\mathrm{Sr}}$ vs. Acid Concentration with Diphonix ${ }^{\circledR}$ Resin $\mathrm{MSA}+0.5 \mathrm{M} \mathrm{HNO}_{3}$

\begin{tabular}{|c|c|c|c|l|}
\hline$[\mathrm{MSA}]$ & {$\left[{\left.\mathrm{H} 3 \mathrm{O}^{+}\right]}^{+}\right.$} & $\mathbf{D}_{\text {sr }}$ (Wet) & $\mathbf{D}_{\text {sr }}$ (Dry) & Notes \\
\hline 0 & 0.5 & $\mathbf{1 6 . 8 7}$ & $\mathbf{4 8 . 1 9}$ & \\
\hline 0.25 & 0.75 & $\mathbf{8 . 0 0}$ & $\mathbf{2 2 . 8 5}$ & \\
\hline 0.5 & 1 & $\mathbf{4 . 4 3}$ & $\mathbf{1 2 . 6 5}$ & \\
\hline 1 & 1.5 & $\mathbf{2 . 0 7}$ & $\mathbf{5 . 9 1}$ & \\
\hline 1.5 & 2 & $\mathbf{1 . 1 5}$ & $\mathbf{3 . 2 8}$ & \\
\hline 2 & 2.5 & $\mathbf{- 0 . 2 5}$ & $-\mathbf{0 . 7 1}$ & not included on log-log plot \\
\hline 3 & 3.5 & $\mathbf{0 . 5 4}$ & $\mathbf{1 . 5 3}$ & \\
\hline 4 & 4.5 & $\mathbf{0 . 7 3}$ & $\mathbf{2 . 0 9}$ & \\
\hline
\end{tabular}

MSA only

\begin{tabular}{|c|c|c|c|l|}
\hline$[\mathrm{MSA}]$ & {$\left[\mathrm{H}^{+} \mathrm{O}^{+}\right]$} & $\mathbf{D}_{\mathrm{sr}}$ (Wet) & $\mathbf{D}_{\mathrm{Sr}}$ (Dry) & Notes \\
\hline & & & & $\begin{array}{l}\text { This [H3O+] is not known. } \\
\text { Assumption made based on } \\
\text { tracer [HCl] = 0.0025M did not } \\
\text { fit curve. Therefore, [H3O+] } \\
\text { assumed based on slope = 2. }\end{array}$ \\
\hline 0.25 & 0.15 & $\mathbf{1 6 0 . 8 6}$ & $\mathbf{4 5 9 . 5 9}$ & \\
\hline 0.5 & 0.5 & $\mathbf{7 9 . 1 5}$ & $\mathbf{2 2 6 . 1 5}$ & \\
\hline 1 & 1 & $\mathbf{1 5 . 7 9}$ & $\mathbf{4 5 . 1 1}$ & \\
\hline 1.5 & 1.5 & $\mathbf{2 . 3 0}$ & $\mathbf{1 4 . 4 1}$ & \\
\hline 2 & 2 & $\mathbf{- 1 . 9 5}$ & $\mathbf{- 5 . 5 7}$ & not included on log-log plot \\
\hline 3 & 3 & $\mathbf{0 . 8 7}$ & $\mathbf{2 . 4 9}$ & \\
\hline 4 & 4 & $\mathbf{1 . 7 3}$ & $\mathbf{4 . 9 5}$ & \\
\hline
\end{tabular}




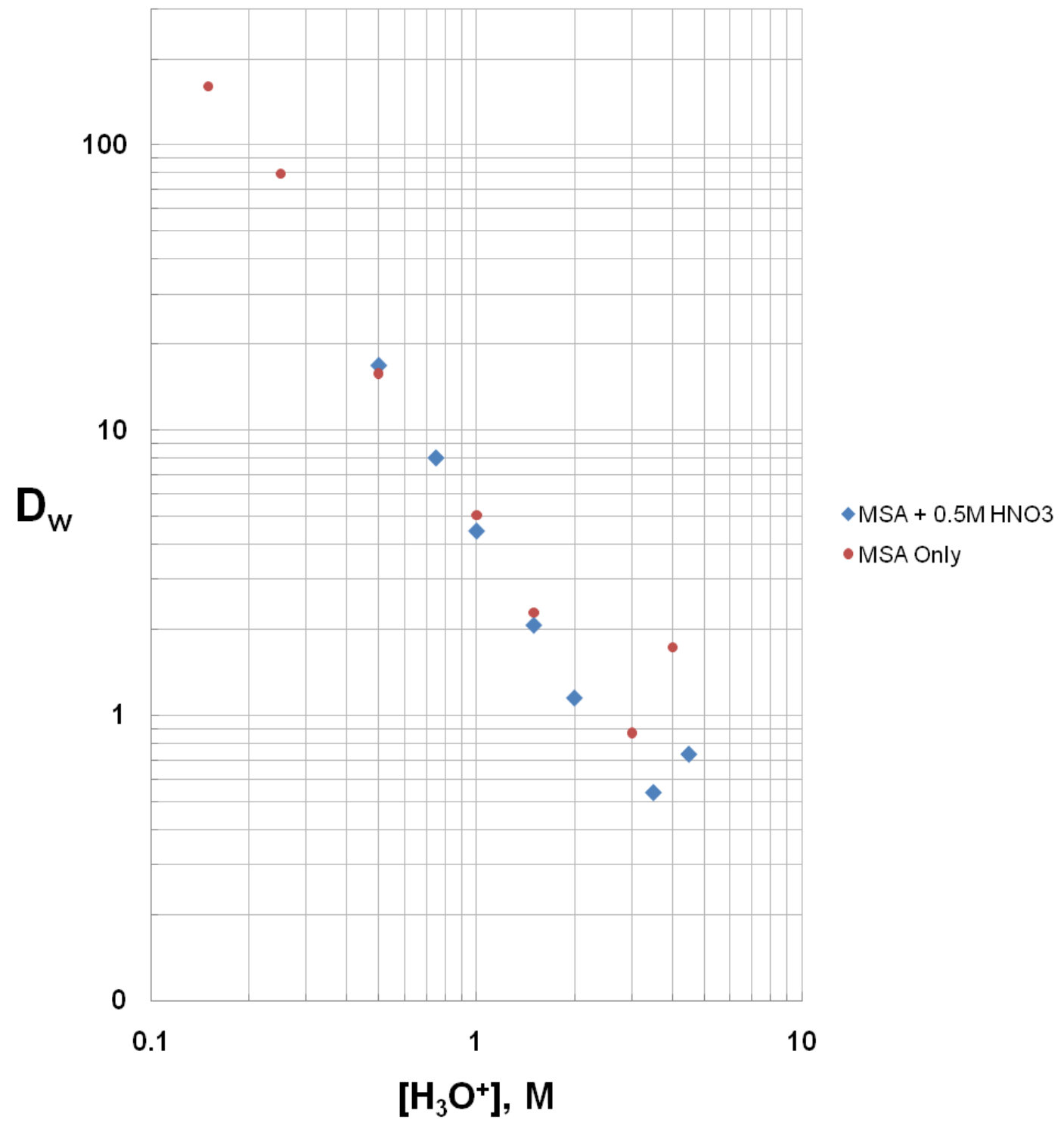

Figure 3: $\mathrm{D}_{\mathrm{sr}}$ vs. $\mathrm{H}_{3} \mathrm{O}^{+}$Concentration on Diphonix ${ }^{\circledR}$ Resin (Wet Weight Basis) 


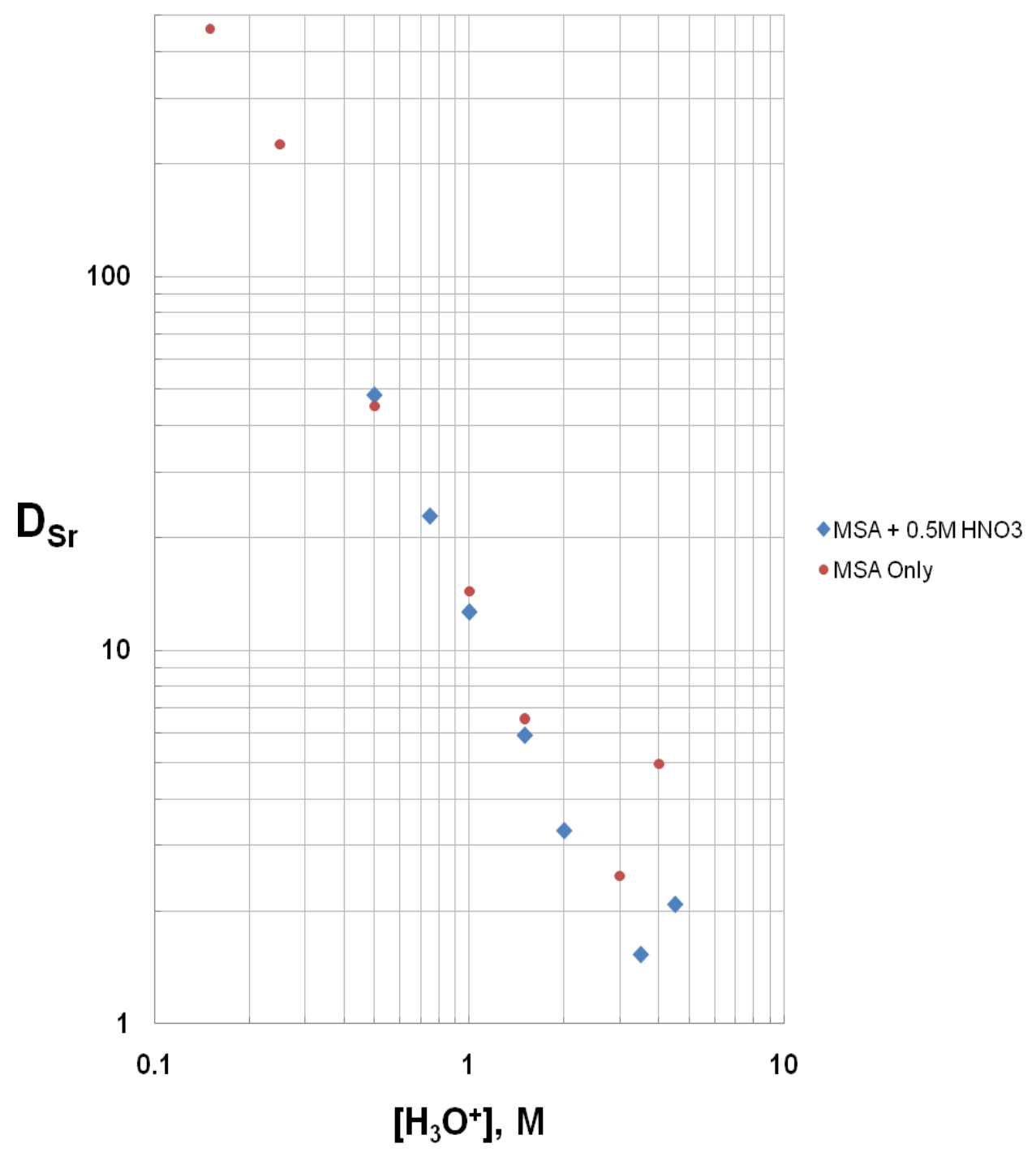

Figure 4: $\mathrm{D}_{\mathrm{sr}}$ vs. $\mathrm{H}_{3} \mathrm{O}^{+}$Concentration on Diphonix ${ }^{\circledR}$ Resin (Dry Weight Basis)

\subsection{Strontium Uptake Suppression by Potassium and Calcium on Diphonix ${ }^{\circledR}$}

To assess the effect of potassium and calcium levels expected in normal human urine, we carried out an experiment to determine the concentrations of these metals that begin to suppress the extraction of strontium. Stock solutions were made from the salts $\mathrm{Ca}\left(\mathrm{NO}_{3}\right)_{2} \cdot 4 \mathrm{H}_{2} \mathrm{O}$ and $\mathrm{KNO}_{3}$ at nominally $0.4 \mathrm{M}$ salt in $0.40 \mathrm{M} \mathrm{MSA}$. The calcium nitrate tetrahydrate salt stock was analyzed by ion chromatography with electrical conductivity detection to ensure an accurate concentration for $\mathrm{Ca}^{2+}$. From the results of this analysis, the relative standard deviation (RSD) for triplicate measurements was $2.14 \%$, with an average concentration of $0.338 \mathrm{M}$, and the standard calibrators deviated from $0.23 \%$ to 
$7.4 \%$ about the best-fit curve for the least-squares regression. From these stocks were prepared a series of dilutions in 0.40 M MSA for each salt, which were then spiked with $\mathrm{Sr}-85$ tracer and contacted with Diphonix resin at a phase ratio between 1:50 and 1:40 $(\mathrm{g} / \mathrm{mL})$. The general procedure followed for the extraction is described in Figure 1.

The results of this experiment listed in Table 6 , and plotted for $D_{S r}$ as a function of individual salt concentrations in Figure 5, show that suppression of strontium uptake on Diphonix ${ }^{\circledR}$ resin begins at approximately $0.005 \mathrm{M} \mathrm{Ca}^{2+}$ and $0.05 \mathrm{M} \mathrm{K}^{+}$in $0.4 \mathrm{M} \mathrm{MSA}$. Calcium is expected to diminish strontium retention more than alkali metals at a given concentration because of its second-order cation exchange modality. Given that calcium and potassium are present in normal human urine at $50 \mathrm{mM}$ and $100 \mathrm{mM}$, respectively, and that these values can vary widely with diet and disease state, it would be reasonable to aim for at least a 10-50 fold reduction in one or both of these metals to avoid breakthrough of strontium upon washing a loaded Diphonix column. Table 6: Sr-85 Uptake Suppression on Diphonix ${ }^{\circledR}$ Resin by Calcium and
Potassium in 0.4 M MSA

\begin{tabular}{|c|c|c|c|}
\hline$\left[\mathbf{C a}^{2+}\right], \mathbf{M}$ & $\mathbf{D}_{\mathbf{S r}}$ (Wet) & $\mathbf{D}_{\mathbf{S r}}$ (Dry) & \% Suppression \\
\hline \hline 0 & 31 & 88 & 0 \\
\hline 0.0004 & 28 & 81 & 8 \\
\hline 0.0008 & 28 & 80 & 10 \\
\hline 0.004 & 24 & 69 & 22 \\
\hline 0.008 & 18 & 51 & 43 \\
\hline 0.04 & 8.3 & 24 & 73 \\
\hline 0.08 & 4.6 & 13 & 85 \\
\hline 0.2 & 3.4 & 10 & 89 \\
\hline
\end{tabular}

\begin{tabular}{|c|c|c|c|}
\hline$\left[\mathbf{K}^{+}\right], \mathbf{M}$ & $\mathbf{D}_{\mathbf{S r}}$ (Wet) & $\mathbf{D}_{\mathbf{S r}}$ (Dry) & \% Suppression \\
\hline \hline 0 & 30 & 85 & 0 \\
\hline 0.0005 & 31 & 88 & -4 \\
\hline 0.001 & 32 & 90 & -6 \\
\hline 0.005 & 30 & 87 & -2 \\
\hline 0.01 & 27 & 78 & 9 \\
\hline 0.05 & 26 & 75 & 12 \\
\hline 0.1 & 17 & 48 & 43 \\
\hline 0.2 & 12 & 33 & 61 \\
\hline
\end{tabular}




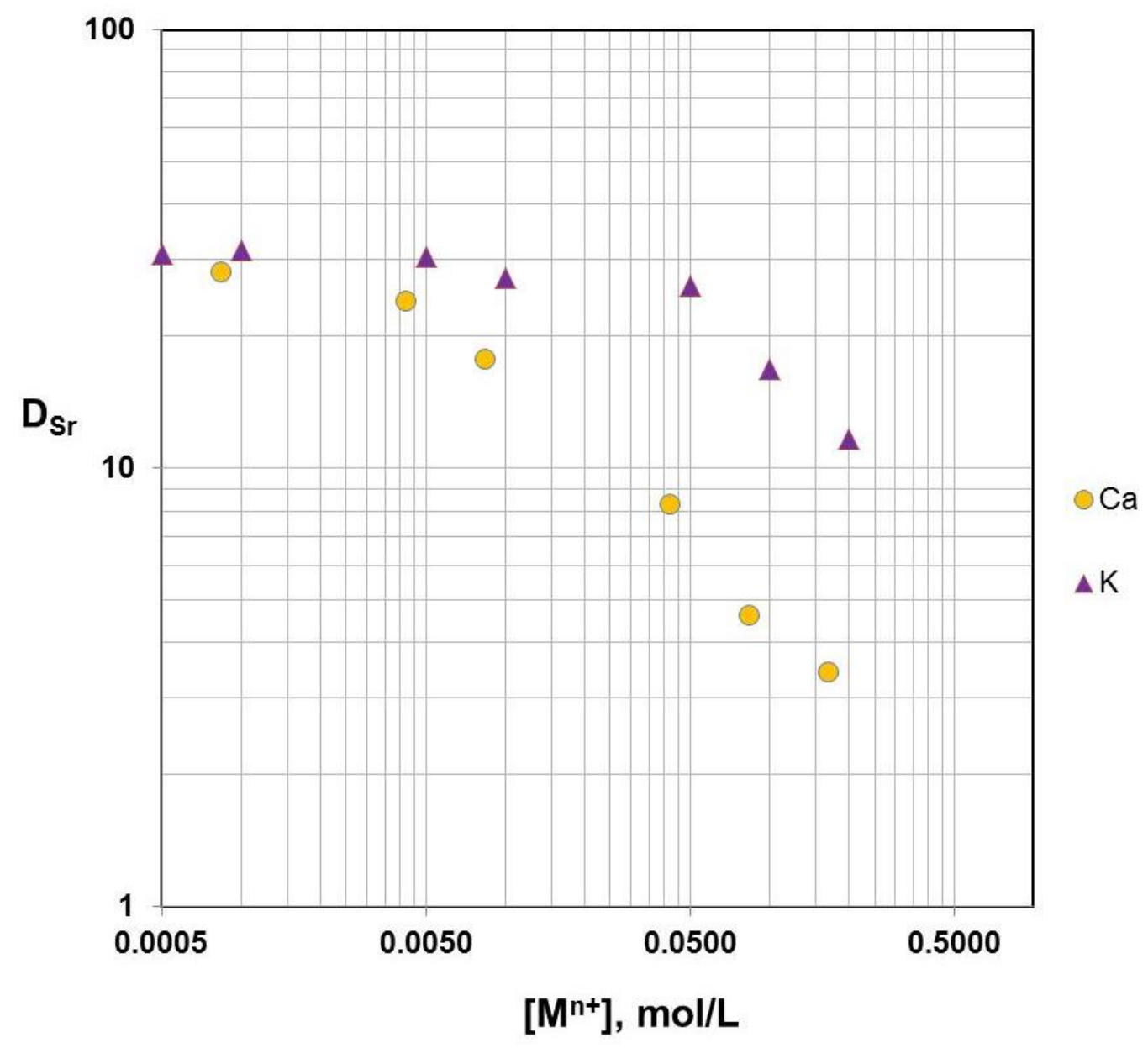

Figure 5: $\mathrm{D}_{\mathrm{Sr}}$ Vs. $\mathrm{Ca}^{2+}$ and $\mathrm{K}^{+}$Concentration in $0.40 \mathrm{M}$ MSA on Diphonix ${ }^{\circledR}$ Resin for a Phase Ratio of 1:20 (g/mL, Wet Weight Basis) Measured by Radiotracer

These results have also been skewed by an over-loading of the resin. To evaluate this possibility, spot checks were performed at $0.1 \mathrm{M} \mathrm{MSA}$ and salt concentrations that correspond to approximately 50\% suppression (or $D_{w} \sim 15$ ) under the above conditions $\left(0.01 \mathrm{M} \mathrm{Ca}^{2+}\right.$ and $0.1 \mathrm{M} \mathrm{K}^{+}$in $\left.0.4 \mathrm{M} \mathrm{MSA}\right)$. The competition for the resin between metal species increased by approximately $30 \%$ when the $\mathrm{H}^{+}$ concentration was reduced (see Table 7). These data indicate that nominal $D_{S r}$ values increased by two-fold by use of 0.1 M MSA from 0.4 M MSA. Achieving distribution ratios of 100 or greater at acid concentrations expected for loading of the species of interest is often a good sign for implementing the separation on a typical column size. 
Table 7: Spot Checks for Sr Uptake on Diphonix® Resin Suppression by $\mathrm{Ca}^{2+}$ and $\mathrm{K}^{+}$in $0.1 \mathrm{M}$ MSA

\begin{tabular}{|l|c|c|c|}
\hline \multicolumn{1}{|c|}{ Metal } & {$\left[\mathbf{M}^{\mathbf{n}+}\right], \mathbf{M}$} & $\mathbf{D}_{\mathbf{S r}}$ & Suppression, \% \\
\hline & 0.00 & 436 & \\
\hline Calcium & 0.01 & 108 & 75 \\
\hline Potassium & 0.10 & 116 & 73 \\
\hline
\end{tabular}

\section{5 $D_{\mathrm{Na}}$ versus MSA Concentration on Diphonix ${ }^{\circledR}$ Resin}

There is a dearth of published data for the uptake of alkali metals on Diphonix ${ }^{\circledR}$ resin. The simplest way to gather data on how sodium behaves on Diphonix ${ }^{\circledR}$ resin with respect to MSA concentration is to use a Na-22 tracer, which will give ideal behavior, although it will not reveal how sodium works at high millimolar quantities from urine. A series of aqueous MSA solutions was prepared and spiked with a $\mathrm{Na}-22$ tracer. Samples were prepared and tested according to the diagram in Figure 1. Acid dependency data for both $D_{\mathrm{Sr}}$ and $D_{\mathrm{Na}}$ are displayed in Table 8 and plotted in Figure 6 for comparison. Note that the slopes for the linear portion of each curve $(-1$ for $\mathrm{Na}$ and 2 for $\mathrm{Sr}$ ) indicate the displacement of hydrogen ions to the extent expected for ion exchange. Deviations from this behavior can be attributed to electrolyte intrusion and high ionic strength effects.

Table 8: $D_{\mathrm{Na}}$ and $D_{\mathrm{Sr}}$ vs. Acid Concentration on Diphonix ${ }^{\circledR}$ Resin

\begin{tabular}{|c|c|c|c|}
\hline$\left[\mathrm{H}_{3} \mathrm{O}^{+}\right], \mathrm{M}$ & $D_{w, N a}$ & $D_{w, s r}$ & Notes \\
\hline 0.10 & 10 & & \\
\hline 0.15 & -- & 161 & $\begin{array}{l}\text { This }\left[\mathrm{H}_{3} \mathrm{O}^{+}\right] \text {is not known. Assumption made } \\
\text { based on tracer }[\mathrm{HCl}] \text { from } \mathrm{Sr}-85 \text { of } 0.0025 \mathrm{M} \text {, } \\
\text { as } \mathrm{D}_{\mathrm{w}} \text { did not fit curve. Therefore, }\left[\mathrm{H}_{3} \mathrm{O}^{+}\right] \\
\text {assumed based on slope of } 2 \text {. }\end{array}$ \\
\hline 0.25 & 4.1 & 79 & \\
\hline 0.5 & 2.1 & 16 & \\
\hline 1 & -- & 5.0 & Na Stock not acid-spiked with MSA. \\
\hline 1.5 & 0.69 & 2.3 & \\
\hline 2 & 1.0 & -2.0 & $\mathrm{D}_{\mathrm{w}, \mathrm{Sr}}$ not included on log-log plot. \\
\hline 3 & 6.0 & 0.87 & \\
\hline \multirow[t]{3}{*}{4} & 1.0 & 1.7 & $\mathrm{IX}=$ ion exchange region of acid dependency \\
\hline & Slope $\mathrm{Na}$ (IX) & Slope $\operatorname{Sr}(\mathrm{IX})$ & \\
\hline & -1.1 & -1.8 & \\
\hline
\end{tabular}




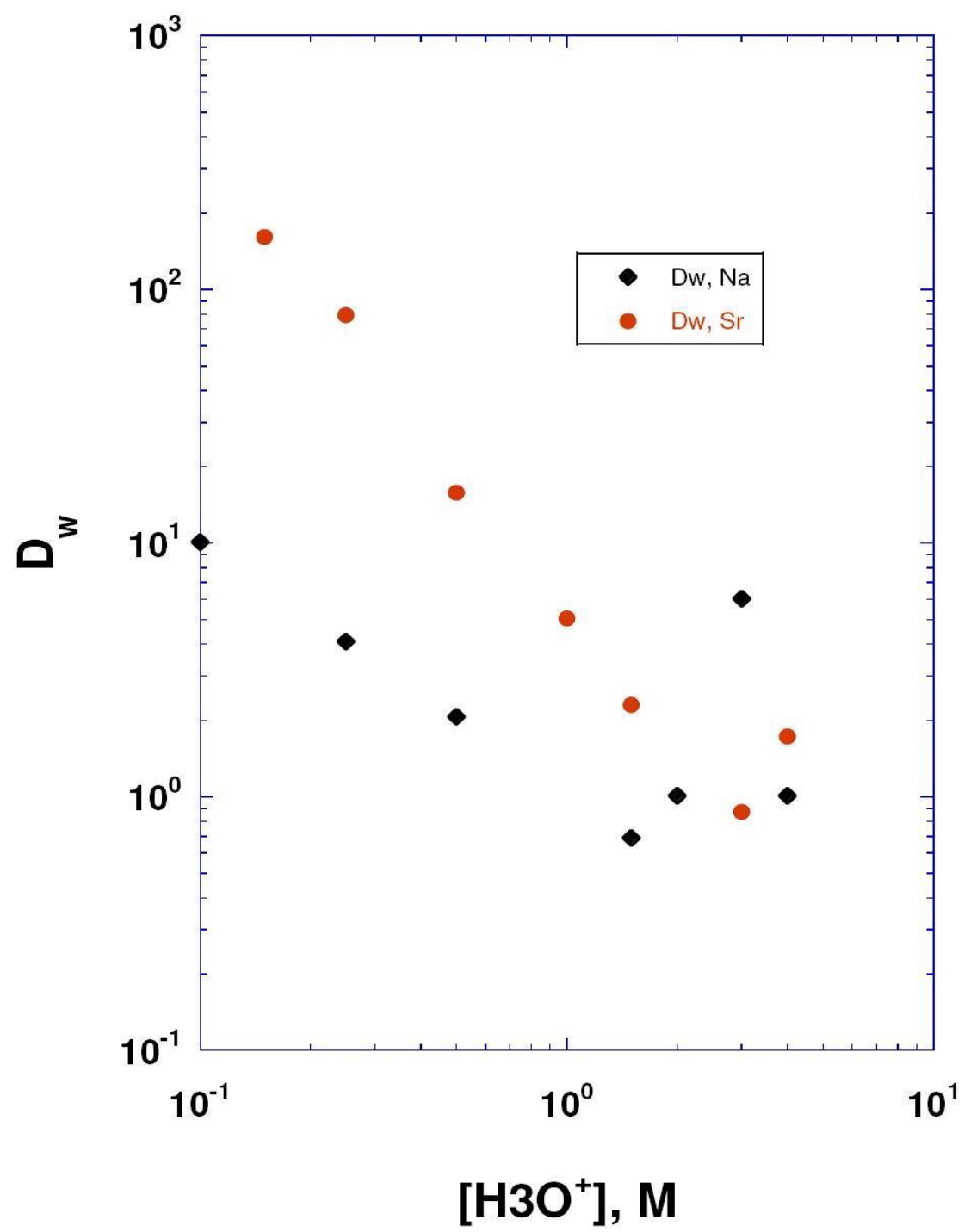

Figure 6: $D_{\mathrm{Na}}$ and $\mathrm{D}_{\mathrm{Sr}}$ vs. $\mathrm{H}_{3} \mathrm{O}^{+}$Concentration on Diphonix ${ }^{\circledR}$ Resin

\section{6 $\mathrm{D}_{\mathrm{Sr}}$ and $\mathrm{D}_{\mathrm{Na}}$ versus MSA Concentrations with $\mathrm{NaCl} / \mathrm{KCl}$ on Diphonix ${ }^{\circledR}$ Resin}

A baseline for ideal behavior on Diphoni ${ }^{\circledR}$ resin was established by the previous work. Approaching the conditions expected for urine extractions, the addition of millimolar quantities of salts to the matrix was tested. In the interest of checking tracer data with macroscopic salt data in the same matrix, these acid dependencies were acquired by radiometric measurements and by inductively coupled plasma atomic emission spectrometry (ICP-AES). We explored the effect of varying MSA concentration at a phase ratio of $1: 20(\mathrm{~g} / \mathrm{mL})$ in the presence of $100 \mathrm{mM} \mathrm{NaCl}$ and $100 \mathrm{mM} \mathrm{KCl}$ on $D_{\mathrm{Sr}}$ and $D_{\mathrm{Na}}$. Figure 7 shows acid dependency data for both $D_{\mathrm{Sr}}$ and $\mathrm{D}_{\mathrm{Na}}$ determined with 
radiotracers (see Figure 1), and Figure 8 shows comparable data obtained with ICPAES.

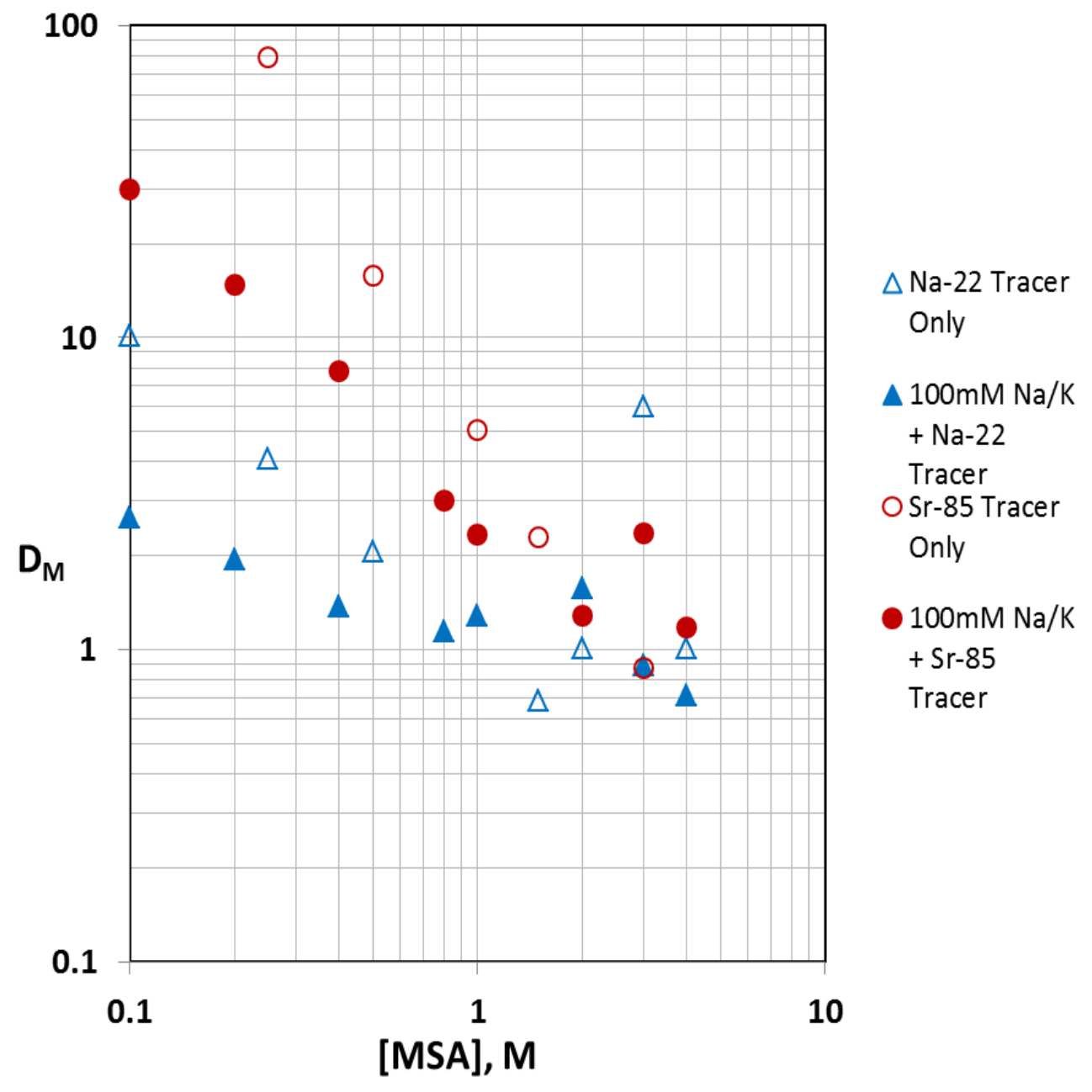

Figure 7: $D_{\mathrm{Na}}$ and $D_{\mathrm{Sr}}$ vs. MSA Concentration with $100 \mathrm{mM} \mathrm{NaCl} / \mathrm{KCl}$ on Diphonix $\circledast$ Resin for a Phase Ratio of 1:20 (g/mL, Wet Weight Basis) Measured by Radiotracer 


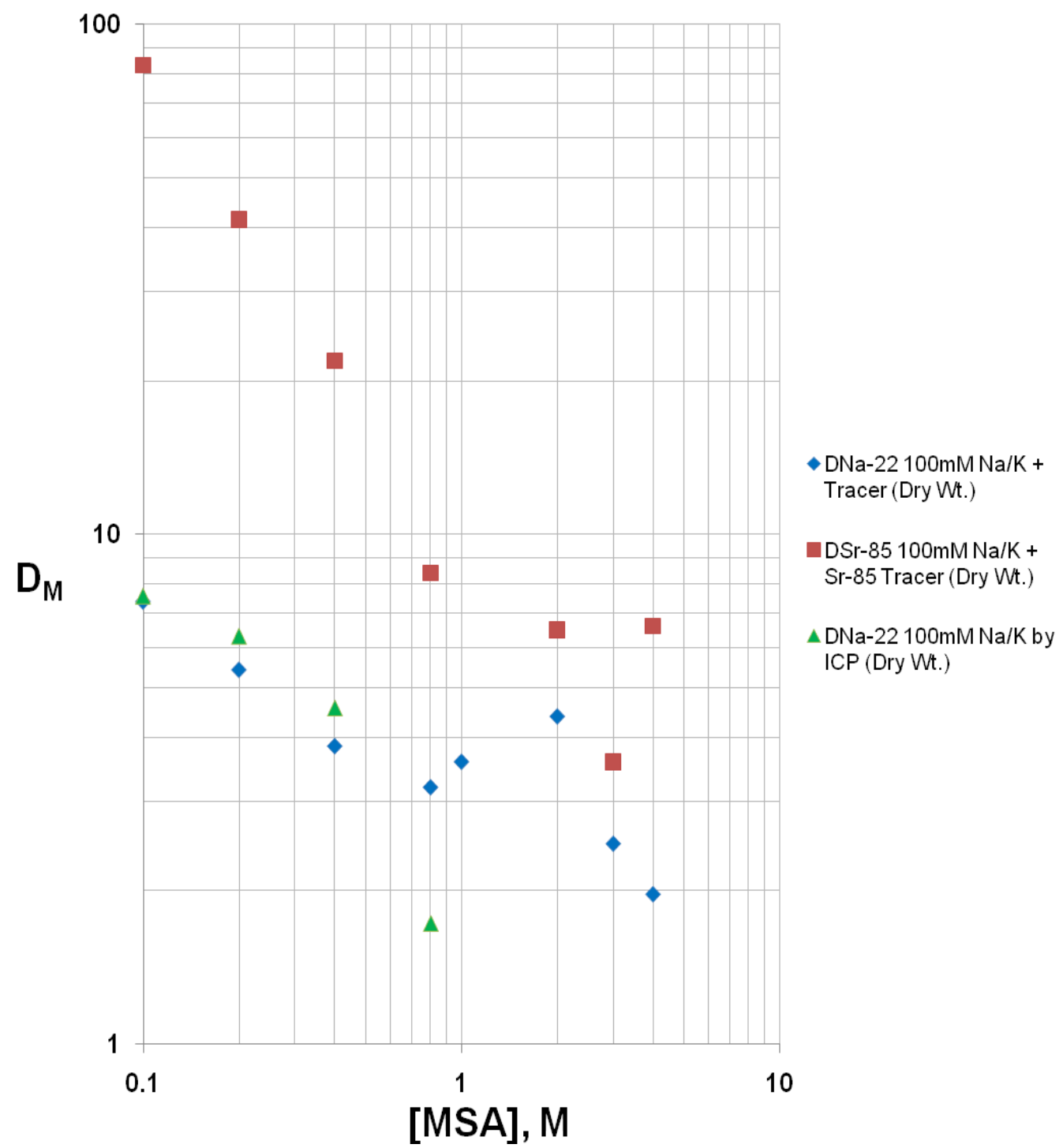

Figure 8: $D_{\mathrm{Na}}$ and $D_{\mathrm{Sr}}$ vs. MSA Concentration with $100 \mathrm{mM} \mathrm{NaCl} / \mathrm{KCl}$ on Diphonix $\AA$ Resin for a Phase Ratio of 1:20 (g/mL, Wet Weight Basis) Measured by Radiotracer and ICP-AES (Na only)

Values for $D_{\mathrm{Na}}$ for each analysis method compare well with each other at $2 \%$, $14 \%$, and $16 \%$ difference between averages in $0.1 \mathrm{M}, 0.2 \mathrm{M}$, and $0.4 \mathrm{M} \mathrm{MSA}$, respectively. At $0.8 \mathrm{M} \mathrm{MSA}$, these values begin to deviate from one another significantly. These data indicate that selectivity for $\mathrm{Sr} / \mathrm{Na}$ drops by an estimated factor of three from acid-only solutions to $100 \mathrm{mM} \mathrm{NaCl} / \mathrm{KCl}$ at a given low MSA concentration, for example, 0.2 M MSA. Therefore, a study was conducted to determine the effect on strontium and sodium extraction by Diphonix ${ }^{\circledR}$ resin by varying $\mathrm{NaCl}$ and $\mathrm{KCl}$ concentrations from 0 to $0.2 \mathrm{M}$ each with $0.1 \mathrm{M}$ and $0.2 \mathrm{M} \mathrm{MSA}$. These experiments were performed for phase ratios of 1:10, 1:20, and 1:30 $(\mathrm{g} / \mathrm{mL})$ to simulate the washing 
of a single-plate column with ten to thirty column volumes. These data would provide good input for the modeling of a column separation. Sample preparation was carried out by radiotracer analysis as described in Figure 1.

In Figure 9, the distribution ratios for strontium are plotted versus salt concentration and show very little differences across the three phase ratios, all other conditions being the same; the distribution ratios do not differ much and, in many cases, are almost identical. The largest difference occurs for the $0.1 \mathrm{M}$ salt in $0.2 \mathrm{M}$ MSA samples, where the RSD is $17 \%$, which may be attributable to non-ideal behavior. All indications are that none of these phase ratios leads to an overloading of the resin. Figure 10 presents the $D_{S r}$ values versus ionic strength, which shows that, at least at ideal salt activities, the data are reproducible. Verification of the distribution ratio for strontium (converted to wet weight basis based upon results in Section 3.3) for $0.1 \mathrm{M}$ salt in $0.1 \mathrm{M} \mathrm{MSA}$ at the $1: 20$ phase ratio is $6 \%$ different from the replicate condition found in Figure 8. Additionally, when the MSA concentration is increased two-fold, the distribution ratios diminish by roughly four-fold, which follows the inverse second-order function expected for $\mathrm{Sr}^{2+}$ ion exchange. 


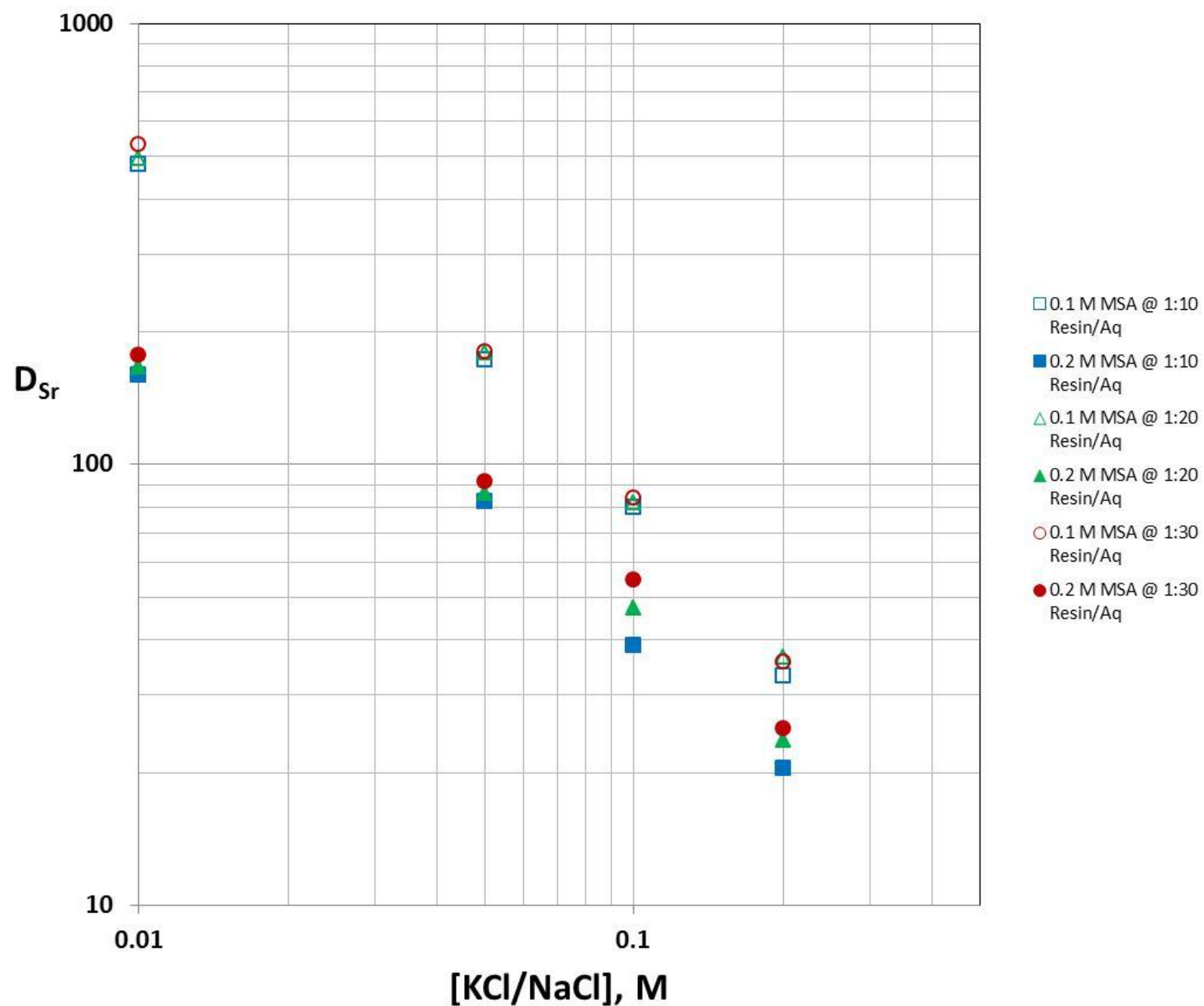

Figure 9. $\mathrm{D}_{\mathrm{Sr}}$ vs. $\mathrm{NaCl} / \mathrm{KCl}$ Concentration in $0.1 \mathrm{M}$ and $0.2 \mathrm{M}$ MSA on Diphonix ${ }^{\circledR}$ Resin (Dry Weight Basis) for 1:10, 1:20, and 1:30 Phase Ratios $(\mathrm{g} / \mathrm{mL})$ 


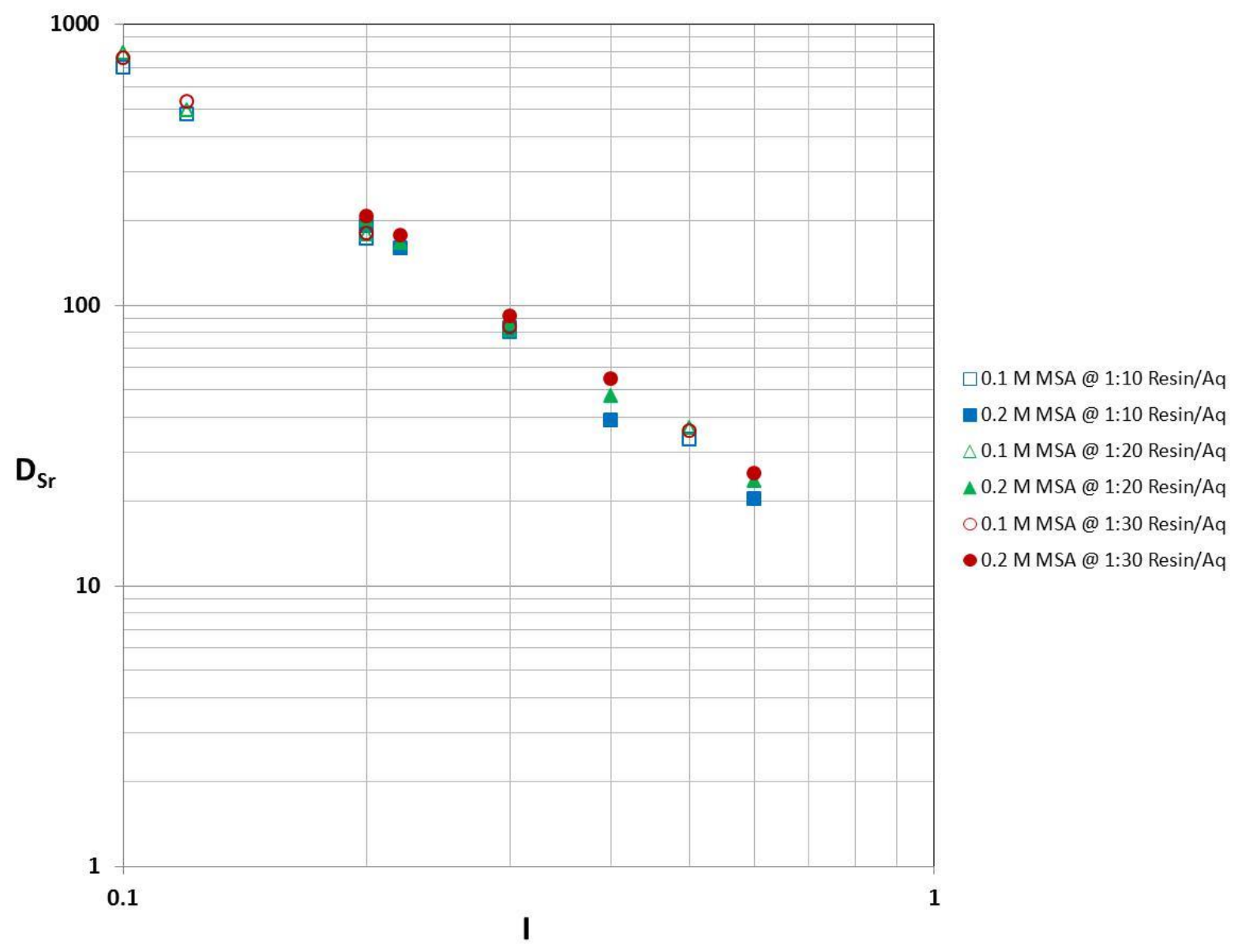

Figure 10: $D_{S r}$ vs. Ionic Strength (I) in $0.1 \mathrm{M}$ and $0.2 \mathrm{M}$ MSA on Diphonix ${ }^{\circledR}$ Resin (Dry Weight Basis) for 1:10, 1:20, and 1:30 Phase Ratios $(\mathrm{g} / \mathrm{mL}$ )

We acquired data for sodium uptake by Diphonix ${ }^{\circledR}$ resin using a Na-22 tracer and the same experimental design indicated in Figure 1. Examining the data in Figures 11 and 12 will again show that the capacity of the resin is not exceeded in even the highest phase ratio $(1: 30)$ based on the convergence of all these values under the same conditions. Summarized data from the $\mathrm{Sr}$ and $\mathrm{Na}$ experiments are shown in Table 9, where the selectivity factor for strontium over sodium is listed in the last column. Selectivity factors are between 8 and 37 for $0-0.2 \mathrm{M}$ salt in $0.1 \mathrm{M} \mathrm{MSA}$ and 6 and 19 for $0-0.2 \mathrm{M}$ salt in 0.2 M MSA. These values are good, considering that, for columns with reasonable plate numbers, selectivity factors of 2 to 3 can separate two metals. 


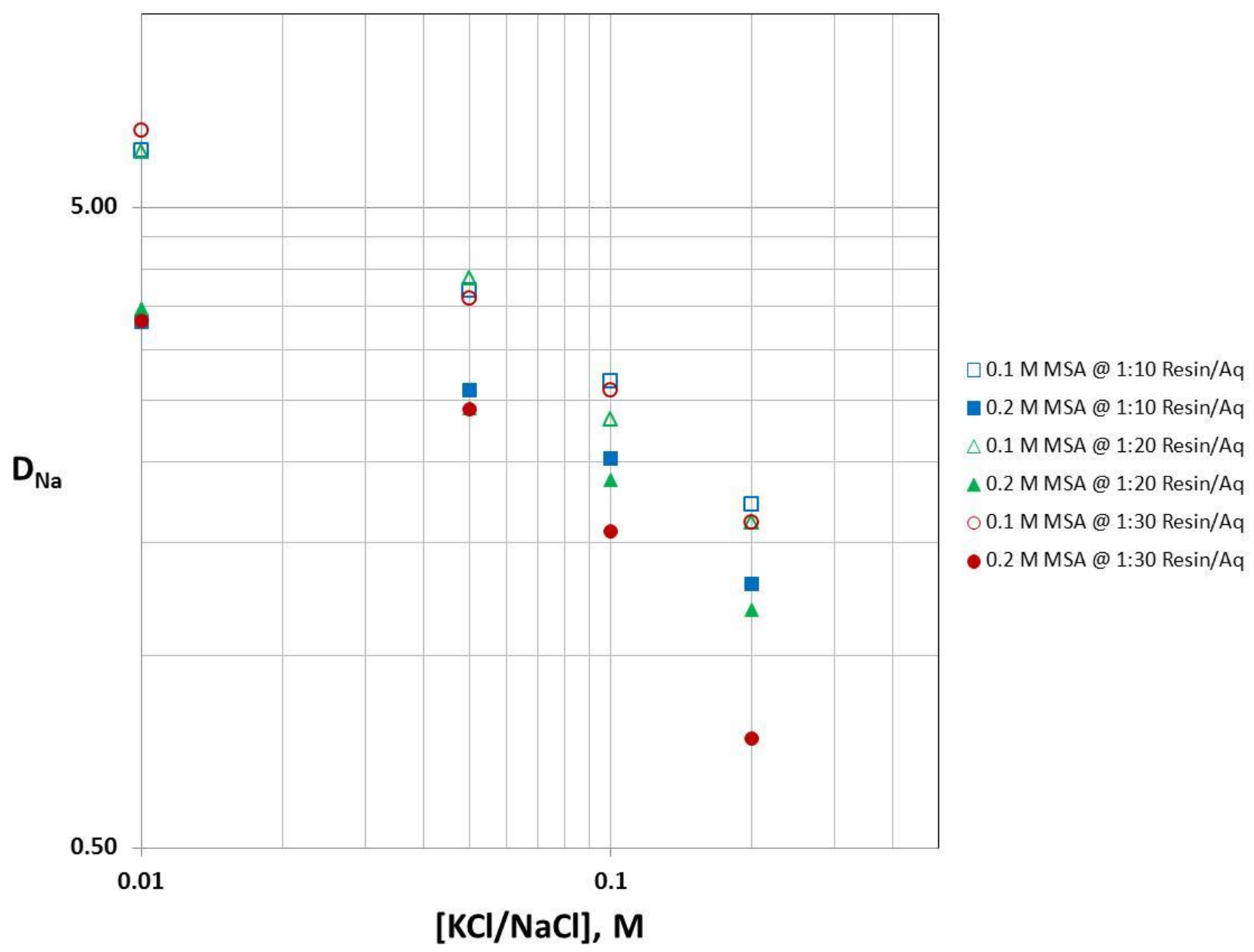

Figure 11: $\mathrm{D}_{\mathrm{Na}}$ vs. $\mathrm{NaCl} / \mathrm{KCl}$ Concentration in $0.1 \mathrm{M}$ and $0.2 \mathrm{M}$ MSA on Diphonix $\AA$ Resin (Dry Weight Basis) for 1:10, 1:20, and 1:30 Phase Ratios $(\mathrm{g} / \mathrm{mL}$ ) 


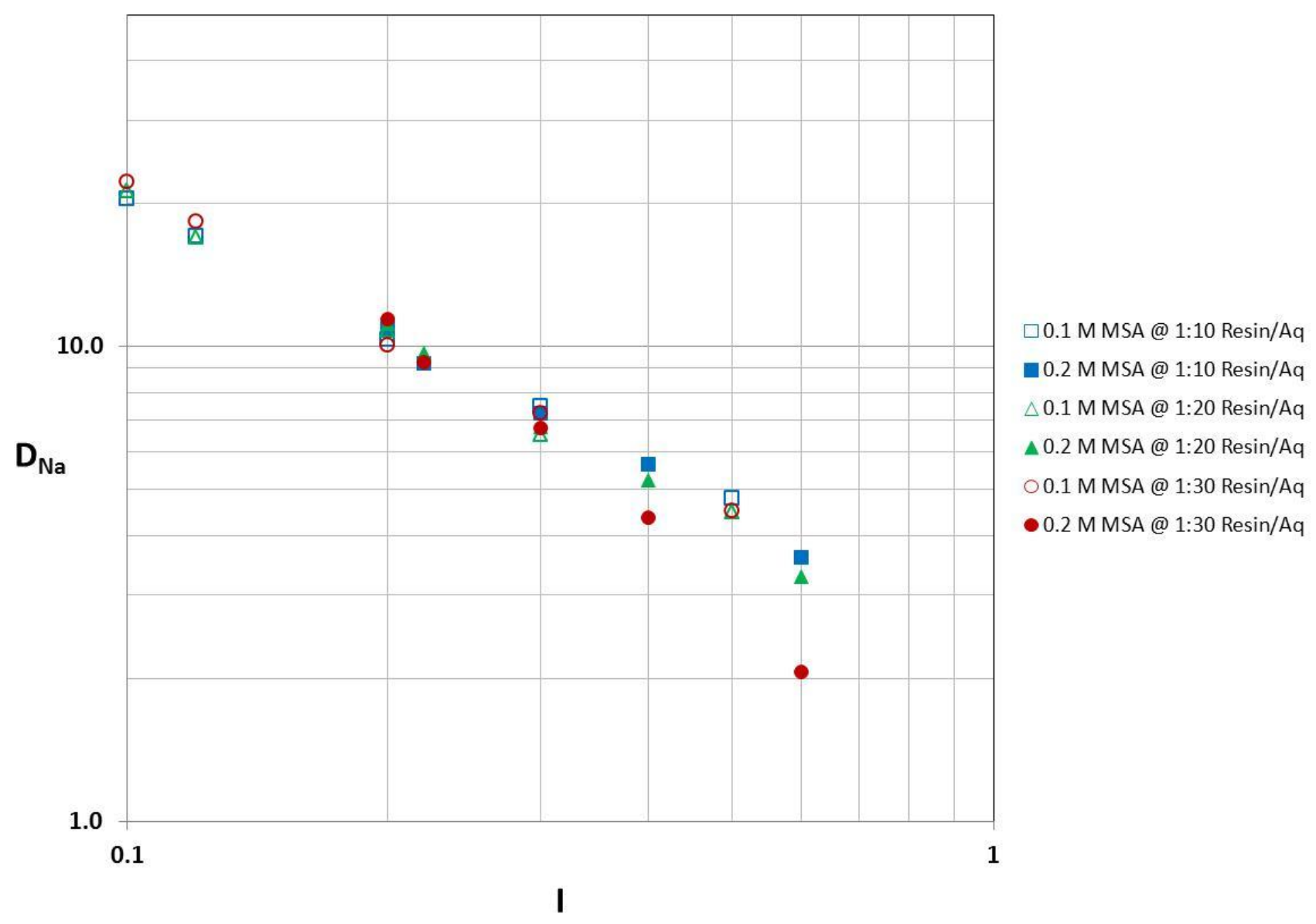

Figure 12: $D_{\mathrm{Na}}$ vs. lonic Strength (I) in $0.1 \mathrm{M}$ and $0.2 \mathrm{M}$ MSA on Diphonix ${ }^{\circledR}$ Resin (Dry Weight Basis) for 1:10, 1:20, and 1:30 Phase Ratios $(\mathrm{g} / \mathrm{mL}$ ) 
Table 9: Acid Dependency Data for Sr and Na Extraction by Diphonix® Resin from 0-0.2 M NaCl/KCl in 0.1 M and 0.2 M MSA for 1:10, 1:20, and 1:30 Phase Ratios (g/mL)

\section{$0.1 \mathrm{M}$ MSA}

\begin{tabular}{|c|c|c|c|c|c|}
\hline $\begin{array}{c}{[\mathbf{N a C l}] /[\mathrm{KCl}],} \\
\mathbf{M}\end{array}$ & $\begin{array}{c}\text { Ionic Strength } \\
\text { (ideal) }\end{array}$ & $\begin{array}{c}\text { Resin:Liquid } \\
(\mathbf{w} / \mathbf{w})\end{array}$ & $\mathbf{D}_{\mathbf{s r}}$ (dry) & $\mathbf{D}_{\mathbf{N a}}$ (dry) & $\begin{array}{c}\text { Selectivity } \\
\left(\mathbf{D}_{\mathbf{s r}} / \mathbf{D}_{\mathbf{N a}}\right)\end{array}$ \\
\hline \hline 0 & 0.1 & $1: 10$ & 700 & 20.5 & 34 \\
\hline 0.01 & 0.12 & $1: 10$ & 480 & 17.1 & 28 \\
\hline 0.05 & 0.2 & $1: 10$ & 173 & 10.3 & 17 \\
\hline 0.1 & 0.3 & $1: 10$ & 80 & 7.46 & 11 \\
\hline 0.2 & 0.5 & $1: 10$ & 33 & 4.79 & 7 \\
\hline 0 & 0.1 & $1: 20$ & 791 & 21.3 & 37 \\
\hline 0.01 & 0.12 & $1: 20$ & 495 & 17.0 & 29 \\
\hline 0.05 & 0.2 & $1: 20$ & 179 & 10.8 & 17 \\
\hline 0.1 & 0.3 & $1: 20$ & 82 & 6.52 & 13 \\
\hline 0.2 & 0.5 & $1: 20$ & 36 & 4.49 & 8 \\
\hline 0 & 0.1 & $1: 30$ & 762 & 22.2 & 34 \\
\hline 0.01 & 0.12 & $1: 30$ & 532 & 18.4 & 29 \\
\hline 0.05 & 0.2 & $1: 30$ & 180 & 10.0 & 18 \\
\hline 0.1 & 0.3 & $1: 30$ & 84 & 7.22 & 12 \\
\hline 0.2 & 0.5 & $1: 30$ & 36 & 4.50 & 8 \\
\hline
\end{tabular}

\section{$0.2 \mathrm{M}$ MSA}

\begin{tabular}{|c|c|c|c|c|c|}
\hline$[\mathrm{NaCl}] /[\mathrm{KCl}], \mathbf{M}$ & $\begin{array}{c}\text { Ionic Strength } \\
\text { (ideal) }\end{array}$ & $\begin{array}{c}\text { Resin:Liquid } \\
(\mathbf{w} / \mathbf{w})\end{array}$ & $\mathbf{D}_{\mathbf{s r}}(\mathbf{d r y})$ & $\mathbf{D}_{\mathrm{Na}}$ (dry) & $\begin{array}{c}\text { Selectivity } \\
\left(\mathbf{D}_{\text {sr }} / \mathbf{D}_{\mathbf{N a}}\right)\end{array}$ \\
\hline \hline 0 & 0.2 & $1: 10$ & 191 & 11.0 & 17 \\
\hline 0.01 & 0.22 & $1: 10$ & 159 & 9.22 & 17 \\
\hline 0.05 & 0.3 & $1: 10$ & 83 & 7.22 & 11 \\
\hline 0.1 & 0.4 & $1: 10$ & 39 & 5.66 & 7 \\
\hline 0.2 & 0.6 & $1: 10$ & 20 & 3.61 & 6 \\
\hline 0 & 0.2 & $1: 20$ & 202 & 11.2 & 18 \\
\hline 0.01 & 0.22 & $1: 20$ & 166 & 9.70 & 17 \\
\hline 0.05 & 0.3 & $1: 20$ & 86 & 6.77 & 13 \\
\hline 0.1 & 0.4 & $1: 20$ & 47 & 5.24 & 9 \\
\hline 0.2 & 0.6 & $1: 20$ & 24 & 3.28 & 7 \\
\hline 0 & 0.2 & $1: 30$ & 207 & 11.4 & 18 \\
\hline 0.01 & 0.22 & $1: 30$ & 177 & 9.29 & 19 \\
\hline 0.05 & 0.3 & $1: 30$ & 91 & 6.75 & 14 \\
\hline 0.1 & 0.4 & $1: 30$ & 55 & 4.36 & 13 \\
\hline 0.2 & 0.6 & $1: 30$ & 25 & 2.07 & 12 \\
\hline
\end{tabular}




\section{7 $\mathrm{D}_{\mathrm{Sr}}$ versus MSA Concentration in Urine on Diphonix ${ }^{\circledR}$ Resin - Urine Treated with MSA and Charcoal}

Characterization of strontium extraction on Diphonix ${ }^{\circledR}$ resin had started with ideal acid dependencies and reached the point of roughly simulating the ionic strength of urine. We next estimated $D_{S r}$ for an actual urine sample. In addition to these sodium and potassium salts, urine contains about 0.2-0.6 M urea, $20 \mathrm{mM}$ phosphates, creatinine, and urate. Initially, we did not know whether or not these organic components interfere with Diphonix ${ }^{\circledast}$ resin extraction. The concern was that $D_{S r}$ for urine can turn out to be significantly lower than that in the salt mixture.

Three milliliter aliquots of uncertified urine were acidified with neat MSA to give concentrations of $0,0.1,0.2,0.3$, and $0.4 \mathrm{M} \mathrm{MSA}$, nominally. A Sr-85 tracer was added in quantity sufficient to attain rates of approximately 5000 counts per minute for the control samples. At a ratio of $1: 100(\mathrm{~g} / \mathrm{mL})$, the acidified and spiked urine was added to glass vials with activated charcoal. The procedure followed is shown in Figure 1. This procedure was also followed for Diphonix ${ }^{\circledR}$ resin extraction at 1:10, 1:20, and 1:30 phase ratios $(\mathrm{g} / \mathrm{mL}$, wet). Triplicate samples were taken for all controls and samples. The data are given in Tables 10 and 11 and Figure 13.

Table 10: Strontium Recoveries from Acidified Urine Charcoal Treatment

\begin{tabular}{|r|r|r|}
\hline [MSA], $M$ & $\begin{array}{c}\text { Charcoal } \\
\text { Recoveries } \\
(\mathrm{n}=4)\end{array}$ & $\begin{array}{c}\text { Relative } \\
\text { Uncertainty }\end{array}$ \\
\hline \hline 0 & $34.9 \%$ & $5.2 \%$ \\
\hline 0.1 & $98.4 \%$ & $3.8 \%$ \\
\hline 0.2 & $97.4 \%$ & $3.5 \%$ \\
\hline 0.3 & $101 \%$ & $3.1 \%$ \\
\hline 0.4 & $99.7 \%$ & $3.2 \%$ \\
\hline
\end{tabular}


Table 11: Average Acid Dependencies for Strontium Extraction from Acidified, Charcoal-Treated Human Urine

Diphonix 1:10 (w/V)

\begin{tabular}{|r|r|r|r|}
\hline & & & \\
[MSA], $\mathbf{~}$ & $\mathbf{D}_{\text {Sr }}$ (wet) & $\mathbf{D}_{\text {Sr }}$ (dry) & RSD \\
\hline \hline 0 & 1228 & 3427 & $3.3 \%$ \\
\hline 0.1 & 112 & 313 & $2.0 \%$ \\
\hline 0.2 & 38.3 & 107 & $1.5 \%$ \\
\hline 0.3 & 16.5 & 45.0 & $0.3 \%$ \\
\hline 0.4 & 12.5 & 36.3 & $0.5 \%$ \\
\hline
\end{tabular}

Diphonix 1:20 (w/V)

\begin{tabular}{|r|r|r|r|}
\hline [MSA], $\mathbf{M}$ & D $_{\mathbf{S r}}$ (wet) & $\mathbf{D}_{\mathbf{S r}}$ (dry) & RSD \\
\hline \hline 0 & 1565 & 4366 & $5.7 \%$ \\
\hline 0.1 & 108 & 301 & $0.7 \%$ \\
\hline 0.2 & 38.7 & 108 & $0.8 \%$ \\
\hline 0.3 & 19.6 & 54.7 & $0.5 \%$ \\
\hline 0.4 & 12.4 & 34.7 & $0.3 \%$ \\
\hline
\end{tabular}

Diphonix 1:30 (w/V)

\begin{tabular}{|r|r|r|r|}
\hline [MSA], $\mathbf{M}$ & $\mathbf{D}_{\mathbf{S r}}$ (wet) & $\mathbf{D}_{\mathbf{S r}}$ (dry) & RSD \\
\hline \hline 0 & 1776 & 4956 & $6.7 \%$ \\
\hline 0.1 & 102 & 285 & $1.4 \%$ \\
\hline 0.2 & 38.5 & 107 & $1.2 \%$ \\
\hline 0.3 & 19.6 & 54.6 & $0.7 \%$ \\
\hline 0.4 & 12.4 & 34.6 & $0.6 \%$ \\
\hline
\end{tabular}




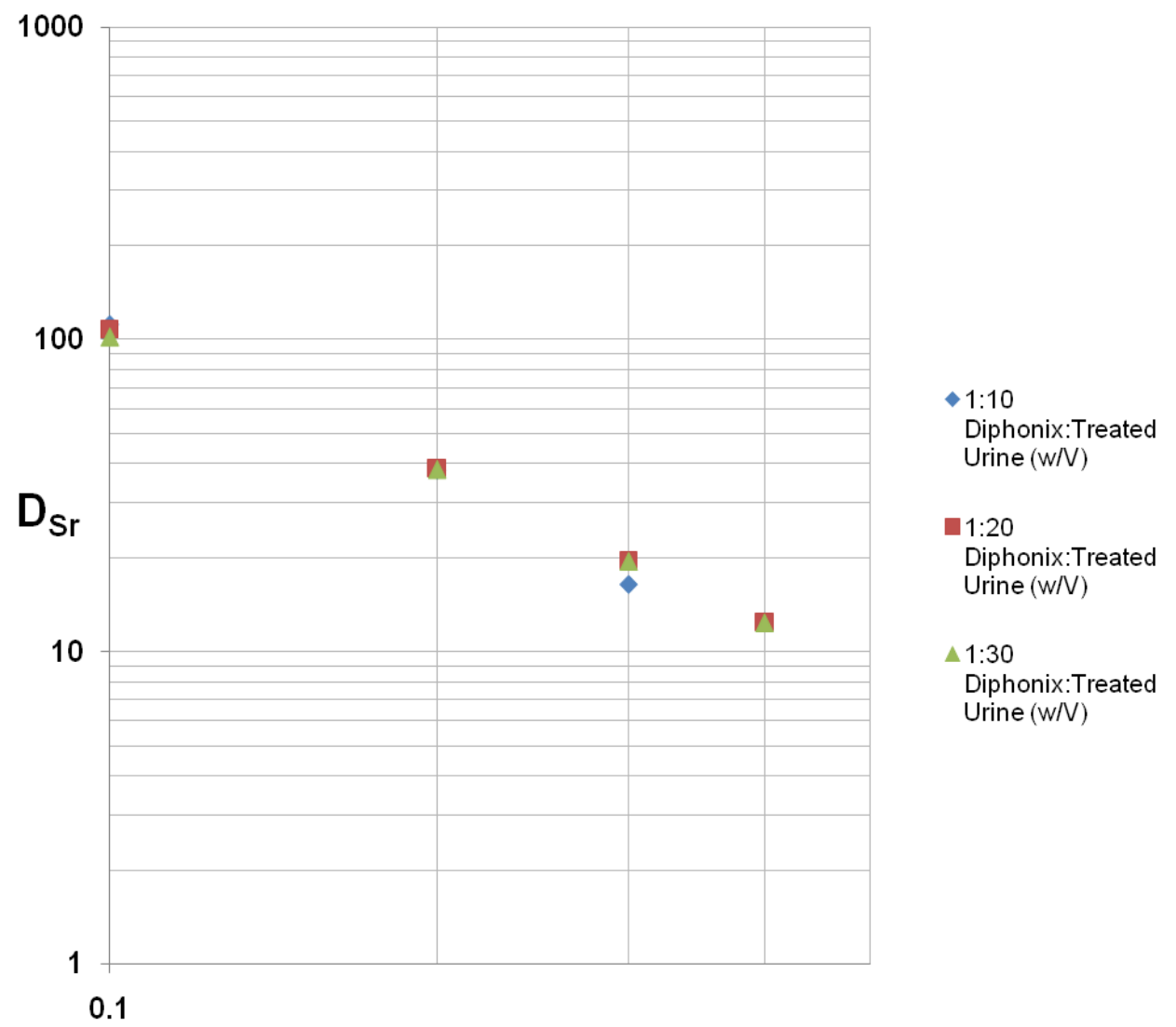

[MSA], M

Figure 13: $D_{S r}$ vs. MSA Concentration in Human Urine on Diphonix ${ }^{\circledR}$ Resin for 1:10, 1:20, and 1:30 Phase Ratios $(\mathrm{g} / \mathrm{mL}$, wet)

All samples containing acid showed no significant losses of strontium to the charcoal treatment, as expected from what Sadi et al. [7] had found. Average $D_{S r}$ values for all of the ratios are extremely reproducible, between $0.3 \%$ and $2.0 \%$ RSD, when MSA is present (Table 11). This is evidence of loading under resin capacity for all ratios. As predicted from the salt simulations, our data in the plot (Figure 13) show that the phase ratios do not affect the distribution of strontium, thus confirming that capacity is not likely to be an issue with normal human urine. When compared to the $D_{S r}$ data for the salts at $0.1 \mathrm{M}$ and $0.2 \mathrm{M} \mathrm{MSA}$, the treated urine behaved like $0.075 \mathrm{M}$ and $0.1 \mathrm{M}$ salts at these MSA concentrations, respectively. Perhaps, if the urine used is comparable in make-up to normal human urine, then this separation is practical, and the next stage ( $\mathrm{Sr}$ resin) should be added to the next set of experiments.

\section{Conclusions}

To summarize, we have demonstrated that urine can be efficiently decolorized and freed of organics by treatment with either nitric acid or MSA followed by contact 
with activated charcoal or an appropriate polymeric sorbent. In addition, we have shown that the removal of organics is not accompanied by measurable loss of radiostrontium from the sample. Sorption of strontium by a commercial, diphosphonic acid-based ion-exchange resin (Diphonix) from acidic aqueous phases containing MSA follows the trend expected for simple ion exchange. This sorption is diminished by high levels of common cationic constituents of urine, in particular, $\mathrm{K}^{+}, \mathrm{Na}^{+}$, and $\mathrm{Ca}^{2+}$, but the adverse effect of these ions is not sufficient to preclude the use of Diphonix as a first step in the separation and preconcentration of Sr-90 from urine for subsequent determination by liquid scintillation analysis.

\section{Acknowledgment}

Work supported by the Center for Disease Control and Prevention under Agreement number 08FED894832. 


\section{References}

[1] U.S. Nuclear Regulatory Commission, Strontium-90, http://www.nrc.gov/readingrm/doc-collections/cfr/part020/appb/Strontium-90.html, accessed July 2013.

[2] Maxwell, S.L., "Rapid Analysis of Emergency Urine and Water Samples," J. Radioanal. Nucl. Chem., 275, 497-502 (2008).

[3] Alvarez, A., N. Navarro, and S. Salvador, J. Radioanal. Nucl. Chem., "New Method for 90Sr Determination in Liquid Samples," 191, 315-332 (1985).

[4] Alvarez, A., and N. Navarro, "Method for Actinides and Sr-90 Determination in Urine Samples," Applied Radiation and Isotopes, 47, 869-873 (1996).

[5] Cobb, J., P. Warwick, R.C. Carpenter, and R.T. Morrison, "Determination of Strontium-90 in Water and Urine Samples using lon Chromatography," Analyst, 119, 1759-1764 (1994).

[6] Yoshinaga J., A. Chatterjee, Y. Shibata, M. Morita, and J.S. Edmonds, "Human Urine Certified Reference Material for Arsenic Speciation," Clinical Chemistry, 46, 1781-1786 (2000).

[7] Sadi, B.B., C. Li, S. Jodayree, E. Lai, V. Kochermin, and G.H. Kramer, "A Rapid Bioassay Method for the Determination of ${ }^{90} \mathrm{Sr}$ in Human Urine," Radiation Protection Dosimetry, 140(1), 41-48 (2010).

[8] Eichrom, Diphonix® Ion Exchange Resin, http://www.eichrom.com/products/info/diphonix resin.aspx, accessed 2016. [9] Maxwell, S., and D. Fauth, "Rapid Column Extractions for Urine," Radioactivity and Radiochemistry, 11(3), 28-34 (2000).

[10] Chiarizia, R., E. P. Horwitz, and R. C. Gatrone, "Uptake of Metal lons by a New Chelating lon-Exchange Resin: Part 2: Acid Dependencies of Transition and Post-Transition Metal lons," Solvent Extraction \& Ion Exchange, 11, 967-985 (1993).

[11] Dietz, M., R. Chiarizia, and E.P. Horwitz, "Effect of Crown Ethers on the lonExchange Behavior of Alkaline Earth Metals. Toward Improved Ion-Exchange Methods for the Separation and Preconcentration of Radium," Analytical Chemistry, 69, 3028-3037 (1997).

[12] Chiarizia, R., J.R. Ferraro, E.P. Horwitz, and K. A. D’Arcy, "Uptake of Metal lons by a New Chelating lon-Exchange Resin. VII. Alkaline Earth Cations," Solvent Extraction \& Ion Exchange, 13, 1063-1082 (1995). 



\section{Argonne}

\section{Nuclear Engineering Division}

Argonne National Laboratory

9700 South Cass Avenue, Bldg. 208

Argonne, IL 60439-4854

www.anl.gov

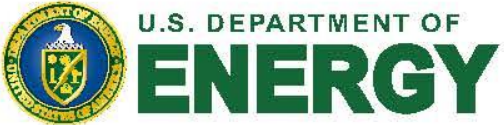

Argonne National Laboratory is a U.S. Department of Energy

laboratory managed by UChicago Argonne, LLC 